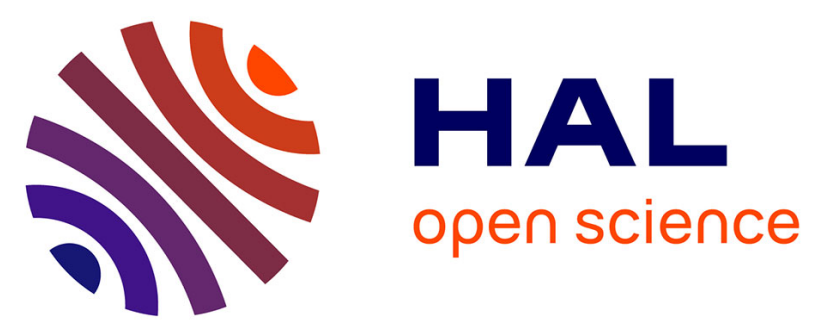

\title{
Petrological and experimental constraints on magma storage for large pumiceous eruptions in Dominica island (Lesser Antilles)
}

Clara Solaro, Caroline Martel, Rémi Champallier, Georges Boudon, Hélène Balcone-Boissard, Michel Pichavant

\section{To cite this version:}

Clara Solaro, Caroline Martel, Rémi Champallier, Georges Boudon, Hélène Balcone-Boissard, et al.. Petrological and experimental constraints on magma storage for large pumiceous eruptions in Dominica island (Lesser Antilles). Bulletin of Volcanology, 2019, 81 (9), 10.1007/s00445-019-1313-x . insu02280177

\section{HAL Id: insu-02280177 https://hal-insu.archives-ouvertes.fr/insu-02280177}

Submitted on 5 May 2020

HAL is a multi-disciplinary open access archive for the deposit and dissemination of scientific research documents, whether they are published or not. The documents may come from teaching and research institutions in France or abroad, or from public or private research centers.
L'archive ouverte pluridisciplinaire $\mathbf{H A L}$, est destinée au dépôt et à la diffusion de documents scientifiques de niveau recherche, publiés ou non, émanant des établissements d'enseignement et de recherche français ou étrangers, des laboratoires publics ou privés. 


\title{
Petrological and experimental constraints on magma storage for large pumiceous eruptions in Dominica island (Lesser Antilles)
}

\author{
Clara Solaro $^{1} \cdot$ Caroline Martel $^{2}$ Rémi Champallier $^{2} \cdot$ Georges Boudon $^{1} \cdot$ Hélène Balcone-Boissard $^{3}$. \\ Michel Pichavant ${ }^{2}$
}

\begin{abstract}
The general question of the generation of large-volume silicic eruptions is here addressed through the experimental determination of the storage conditions of the primary magmas that generated ignimbritic eruptions at Dominica Island (Lesser Antilles) during the 24-51 ka period of time. The basal plinian fallouts and pumice pyroclastic flows from the large-volume $\left(\sim 5 \mathrm{~km}^{3} \mathrm{DRE}\right)$ events of Layou, Roseau and Grand Fond were investigated, together with the smaller ignimbritic eruptions of Grand Bay and Grande Savane. All samples are dacitic (63-66 wt $\left.\% \mathrm{SiO}_{2}\right)$ and contain $~ 30$ vol\% phenocrysts of plagioclase $(\sim 21 \mathrm{vol} \%)$, orthopyroxene $(\sim 5 \mathrm{vol} \%)$ and Fe-Ti oxides $(<1$ vol\%), in a rhyolitic matrix glass. The most differentiated samples contain additional amphibole (up to 5 vol\%) and quartz. Crystallization experiments were performed starting from Layou and Roseau pumice samples at 800 to $900{ }^{\circ} \mathrm{C}, 200$ to $400 \mathrm{MPa}, \sim \Delta \mathrm{NNO}+1$ and for $\mathrm{H}_{2} \mathrm{O}$-saturated and $\mathrm{H}_{2} \mathrm{O}$-undersaturated conditions. The main phase contents, assemblages and compositions of both natural samples were reproduced experimentally at $\sim 850{ }^{\circ} \mathrm{C}, \Delta \mathrm{NNO}+0.6,7-8 \mathrm{wt} \%$ melt $\mathrm{H}_{2} \mathrm{O}$ and $\sim 400 \mathrm{MPa}(\sim 16 \mathrm{~km}$ depth) consistent with magma ponding at the mid-crustal discontinuity. There is also evidence of more differentiated magma batches that may reflect a plumbing system with a significant vertical extension. The relationships between the chamber depth, width and volume argue for eruptions that do not form collapse calderas, in agreement with field evidence. The erupted magma volumes in Dominica are more than five times larger than those emitted in the neighbouring islands (Martinique, Guadeloupe, Montserrat; $<1 \mathrm{~km}^{3}$ ), which may be explained by a locally extensional tectonic context that favoured assembly of large magma bodies, but also by the rarity of frequently draining upper crustal reservoirs (as evidenced on the neighbouring volcanic systems) that favoured deep accumulation of large volumes of magma during this period and time for differentiation to dacitic compositions.
\end{abstract}

Keywords Dominica $\cdot$ Ignimbrite $\cdot$ Dacite $\cdot$ Phase equilibria $\cdot$ Storage conditions

Editorial responsibility: M. Portnyagin

Electronic supplementary material The online version of this article (https://doi.org/10.1007/s00445-019-1313-x) contains supplementary material, which is available to authorized users.

Caroline Martel

caroline.martel@cnrs-orleans.fr

1 Institut de Physique du Globe de Paris (IPGP), CNRS, Université de Paris, Paris, France

2 Institut des Sciences de la Terre d'Orléans (ISTO), UMR 7327, Université d'Orléans - CNRS - BRGM, Orléans, France

3 UMR 7193 Université Paris 06 - CNRS - ISTeP, Sorbonne Universités (UPMC), Paris, France

\section{Introduction}

Island arc subduction magmatism is known to mostly produce andesitic to dacitic eruptions of small volumes $\left(<1 \mathrm{~km}^{3}\right.$ dense rock equivalent (DRE) per eruption), as also reported for the Lesser Antilles arc (Lindsay et al. 2005a). Nevertheless, some systems can produce large-volume silicic eruptions (5 to several $10 \mathrm{~km}^{3}$ DRE/eruption), mostly associated with caldera formation, with important implications in terms of hazard assessment and risk management (Self and Rampino 1981; Self et al. 1984; Heiken and McCoy 1984; Druitt et al. 1989; Allen 2001; Wilson 2001; Reubi and Nicholls 2005; Wilson et al. 2006). The genesis, storage and eruption of large-volume magmas in arc settings are thus key issues to evaluate the impact and mitigate the risk on human society. 
Using thermo-mechanical modelling of heat transfer, Annen and Sparks (2002) calculated that intrusion rates higher than $5.10^{-4} \mathrm{~m} /$ year are necessary to generate large-scale magma bodies in the crust by a process of sill accretion. Such intrusion rates imply periods of high magma production rates (flare-up; de Silva and Gosnold 2007), which could result from high magmatic fluxes from the mantle (at least $10^{-2} \mathrm{~km}^{3} /$ year; Annen 2009), as evidenced for large plutonic batholiths (Lipman 2007; de Silva and Gosnold 2007; de Silva 2008).

Nevertheless, such high magma fluxes can also be detrimental to the growth of large-volume reservoirs. To prevent dike propagation and eruption, recharge rate must be comparable to the viscous relaxation time of the surrounding crust (Jellinek and De Paolo 2003; Degruyter and Huber 2014; Degruyter et al. 2016). Thus, Jellinek and De Paolo (2003) suggested that the production of large magma volumes linked with caldera-forming eruptions derives from long periods $\left(10^{5}-10^{6}\right.$ years) of magma supply in large magma chambers $\left(>10^{2} \mathrm{~km}^{3}\right)$. Warm viscoelastic walls would allow them to deform, thus preventing large overpressures to be generated and promoting growth of the reservoir. Such a storage regime would be favoured in extensional tectonic contexts. To trigger an eruption from these large magma volumes, a critical overpressure must be reached, either by magma inputs $\left(10^{-2}\right.$ to $10^{-1} \mathrm{~km}^{3} /$ year; de Silva 2008) that largely exceed the longterm magma supply rates, and/or a chamber vertically flattened favouring dike generation, magma propagation and eruption (Jellinek and De Paolo 2003).

Whether the storage conditions of such large magma volumes are different, especially in terms of pressure/depth and temperature, from those of small-volume magma chambers, is a key issue in understanding magma generation, growth and eruption conditions at crustal levels. In particular, pressure, temperature and volatile content are essential parameters in controlling magma storage. Several phaseequilibrium studies have been conducted on small-volume magma chambers from subduction zones, suggesting temperatures $(T)$ from 820 to $900^{\circ} \mathrm{C}$ and pressures $(P)$ from 100 to $200 \mathrm{MPa}$ for andesitic to dacitic magmas (e.g. Luhr 1990; Gardner et al. 1995; Barclay et al. 1998; Martel et al. 1998; Sato et al. 1999; Scaillet and Evans 1999; Hammer et al. 2002; Costa et al. 2004; Holtz et al. 2005). In contrast, only a few studies suggest deep storage pressures $\sim 400 \mathrm{MPa}$ for large-volume andesitic reservoirs (Parat et al. 2008; Andújar et al. 2016). On Dominica island, in the Lesser Antilles arc, where large-volume eruptions are known, petrological studies of dome-forming products and pumiceous ignimbrites (Howe et al. ) have suggested crystallization temperatures of $800-990^{\circ} \mathrm{C}$ and oxygen fugacities $\left(f_{\mathrm{O} 2}\right)$ of $\mathrm{NNO}-0.25$ to +0.35 (up to $\mathrm{NNO}+0.7$ in Howe et al. 2014), but pressures of magma storage have not been determined.
We present hereafter a study combining petrological and experimental approaches to constrain the storage conditions of Dominica magmas. Several important issues are addressed such as (i) the depth, temperature and the volatile content of these large silicic pumiceous eruptions; (ii) the possible differences in storage conditions between small- and large-volume eruptions; and (iii) the factors that control the volumes of erupted magma at the scale of the Lesser Antilles arc, from the comparison between Dominica and the neighbouring islands (Martinique, Guadeloupe, Montserrat).

\section{Geological setting, volcanic activity and petrological background}

The Lesser Antilles volcanic arc results from the subduction of the Atlantic oceanic lithosphere below the Caribbean oceanic plate at an average velocity of $\sim 2 \mathrm{~cm} /$ year (Wadge 1984). Built up by 11 main islands, the arc is $800 \mathrm{~km}$ long, with a particular convexity toward the East (Fig. 1). Dominica Island

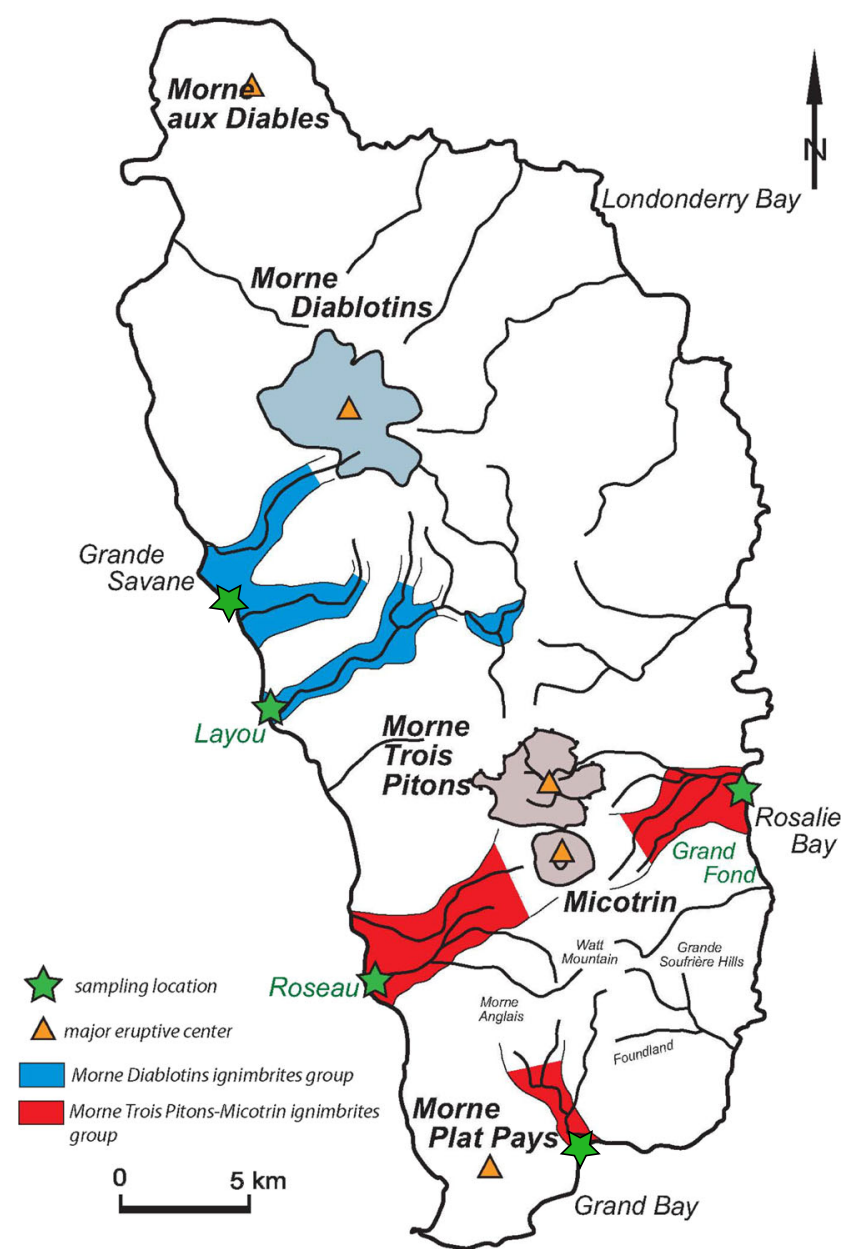

Fig. 1 Dominica Island. Simplified version of Dominica geological map showing the deposit extent of the major pyroclastic density currents. The orange triangles indicate the major eruptive centres and the green stars show the sampling sites (modified after Boudon et al. 2017) 
represents a central point of the arc, from which the southern islands (Dominica to Grenada) form a unique active segment, whereas the northern islands (Dominica to Anguilla) separate into a recent active western limb and an older inactive eastern segment (Bouysse and Westercamp 1990). The active arc hosts 12 volcanic islands.

Dominica Island $\left(15^{\circ} 25 \mathrm{~N}, 61^{\circ} 20 \mathrm{~W}\right)$ is located at the centre of the Lesser Antilles arc between Martinique and Guadeloupe. From North to South, four main active volcanic centres are present: Morne aux Diables, Morne Diablotins, Morne Trois-Pitons-Micotrin and Plat Pays and few minor centres such as Foundland, Morne Watt and Morne Anglais (Fig. 1). The dominant volcanic activity is characterized by dome-forming eruptions but also by large ignimbritic eruptions (Sigurdsson 1972; Carey and Sigurdsson 1980; Smith et al. 2013).

Even if the recent activity (1980-1990) of Dominica has been characterized by phreatic activity originated from the Boiling Lake and the Valley of Desolation (Fournier et al. 2009; Di Napoli et al. 2014; Mayer et al. 2017), work has also been focused on the ignimbrite deposits that extensively outcrop in the central part of the island. In particular, the Pleistocene Roseau Tuff has been fully described (Sigurdsson 1972; Carey and Sigurdsson 1980). Recent on-land stratigraphic and chronological studies have evidenced that the Roseau eruption was not a single event (as previously suggested by Carey and Sigurdsson 1980), but is made of several individual eruptions (Smith et al. 2013; Howe et al. 2014; Boudon et al. 2017). In particular, Boudon et al. (2017) recognized at least three major pumiceous explosive eruptions (volume $\sim 5 \mathrm{~km}^{3}$ DRE/eruption) in the last $50 \mathrm{ky}$ of volcanic activity: Layou (51 ka), Roseau (33 ka) and Grand Fond $(24 \mathrm{ka})$. These eruptions started with a plinian phase producing a relatively thin basal pumice fallout deposit (20 to $70 \mathrm{~cm},<10 \%$ of total erupted volume), followed by voluminous pyroclastic density currents (PDC) producing thick pumiceous deposits filling the valleys (detailed stratigraphy of these three eruptions in Boudon et al. 2017). These authors proposed that the Layou ignimbrites were emitted from Morne Diablotins volcanic centre, and did not originate from Morne Trois Pitons-Micotrin as previously proposed (Roobol and Smith 2004; Lindsay et al. 2005b). Roseau and Grand Fond ignimbrites were emitted from Morne Trois Pitons-Micotrin volcanic centre (Roobol and Smith 2004; Lindsay et al. 2005b). Two other pumiceous PDC deposits have been recognized on the island: Grande Savane and Grand Bay. The Grande Savane outcrops on the West coast, near the village of Salisbury, and has been described as an ignimbritic sequence (Sparks et al. 1980). The volume, the stratigraphic extension and the age of this deposit are still not constrained, but the eruptive centre at the origin of this ignimbritic eruption has been proposed to be the Morne Diablotins volcanic complex (Smith et al. 2013). The Grand Bay ignimbrite outcrops in the South coast, near the village of Berekua, and has been described by Lindsay et al. (2003) and Howe et al. (2014) as a massive, pumice- and lithic-rich PDC deposit. The centre of this ignimbritic eruption, previously assumed to be Plat Pays Volcanic centre (Lindsay et al. 2003) or the Wotten-Waven caldera (Lindsay et al. 2005a; Smith et al. 2013), has recently been proposed to be the complex of Morne Trois Pitons-Micotrin (Boudon et al. 2017).

In light of these data, Dominica appears as an anomaly in the general eruptive behaviour of the Lesser Antilles arc. Indeed, whereas the neighbouring islands of Martinique and Guadeloupe have only one active volcanic centre producing small volume $\left(<1 \mathrm{~km}^{3}\right.$ DRE/eruption) plinian and lava domeforming eruptions (Carazzo et al. 2012), Dominica is characterized by several active volcanic centres and the eruption of five major large-volume ignimbrites (Lindsay et al. 2005a; Boudon et al. 2017).

Geochemical data for pumice samples from ignimbritic eruptions across the island (Grand Bay, Roseau, Layou, Grand Fond, Grande Savane) are available in Howe et al. (2014) and Boudon et al. (2017). The samples have andesitic to dacitic whole-rock compositions (61-66 wt\% $\mathrm{SiO}_{2}, 3.6-$ $6.0 \mathrm{wt} \% \mathrm{Na}_{2} \mathrm{O}+\mathrm{K}_{2} \mathrm{O}$, 5.1-6.5 wt $\%$ FeO; recalculated volatile-free with total iron as $\mathrm{FeO}$ ). Layou and Grande Savane (64-66 wt $\% \mathrm{SiO}_{2}, \sim 5.0$ wt $\% \mathrm{Na}_{2} \mathrm{O}+\mathrm{K}_{2} \mathrm{O}$ ) and Roseau, Grand Bay and Grand Fond (62-63 wt\% $\mathrm{SiO}_{2}$, 4.5-5.0 wt\% $\left.\mathrm{Na}_{2} \mathrm{O}+\mathrm{K}_{2} \mathrm{O}\right)$ are the most and least evolved samples, respectively (Table 1 ).

Pumice samples in ignimbrites (Howe et al. 2014) contain 25-30 vol\% phenocrysts, including plagioclase (15-24 vol\%, $\mathrm{An}_{40-95}$; An: mol\% anorthite), orthopyroxene (0-5 vol\%, $\mathrm{En}_{43-61}$; En: mol\% enstatite), clinopyroxene (0-3 vol\%, $\mathrm{Wo}_{41-44}$; $\mathrm{En}_{36-40}$; Wo: mol\% wollastonite) and Fe-Ti oxides (0-4 vol\%, Mag $_{65-75}$; Mag: mol\% magnetite). Amphiboles are only found in Layou and Grande Savane deposits and few euhedral quartz (1-2\%) are only present in Layou deposits (Boudon et al. 2017). The groundmass glass, which is free of microlites, is rhyolitic (76-78 wt\% $\mathrm{SiO}_{2}, 5-7 \mathrm{wt} \%$ $\mathrm{Na}_{2} \mathrm{O}+\mathrm{K}_{2} \mathrm{O}$ ) and very homogeneous (Howe et al. 2014; Boudon et al. 2017).

Howe et al. (2015) performed a petrologic study on products from lava dome-forming eruptions (block-andash flows and lavas) across the island. These lava dome samples, andesitic to dacitic in composition, have a mineral assemblage similar to the pumice samples in ignimbrites, but show higher crystallinity (about 40-55 vol\%). The lava dome samples also differ from the pumice samples in that they contain basalt to basaltic-andesite enclaves. 
Table 1 Bulk-rock composition of the main ignimbrites from Dominica

\begin{tabular}{|c|c|c|c|c|c|c|c|c|c|}
\hline \multirow[t]{3}{*}{ Oxides (wt $\%$ ) } & \multicolumn{4}{|c|}{ Layou-like group } & \multicolumn{5}{|c|}{ Roseau-like group } \\
\hline & \multicolumn{2}{|l|}{ Layou } & \multicolumn{2}{|c|}{ Grande Savane } & \multicolumn{2}{|l|}{ Roseau } & \multicolumn{2}{|c|}{ Grand Bay } & \multirow{2}{*}{$\begin{array}{l}\text { Grand Fond } \\
\text { Nat } \\
\text { DOM43b1 }\end{array}$} \\
\hline & $\begin{array}{l}\text { Exp } \\
\text { LAY }\end{array}$ & $\begin{array}{l}\text { Nat } \\
\text { Dom41a1 }\end{array}$ & $\begin{array}{l}\text { Exp } \\
\text { GS }\end{array}$ & $\begin{array}{l}\text { Nat } \\
\text { DOM40b }\end{array}$ & $\begin{array}{l}\text { Exp } \\
\text { ROS }\end{array}$ & $\begin{array}{l}\text { Nat } \\
\text { DOM60d1a }\end{array}$ & $\begin{array}{l}\text { Exp } \\
\text { GB }\end{array}$ & $\begin{array}{l}\text { Nat } \\
\text { DOM31 }\end{array}$ & \\
\hline $\mathrm{SiO}_{2}$ & 65.43 & 66.20 & 65.65 & 64.83 & 64.08 & 63.50 & 63.02 & 63.31 & 62.76 \\
\hline $\mathrm{TiO}_{2}$ & 0.46 & 0.38 & 0.37 & 0.45 & 0.51 & 0.54 & 0.63 & 0.51 & 0.54 \\
\hline $\mathrm{Al}_{2} \mathrm{O}_{3}$ & 16.60 & 16.43 & 17.51 & 16.45 & 17.05 & 16.89 & 16.92 & 16.80 & 17.05 \\
\hline $\mathrm{FeO}_{\text {tot }}$ & 5.32 & 4.79 & 4.18 & 5.26 & 5.63 & 6.11 & 6.15 & 5.86 & 6.11 \\
\hline $\mathrm{MnO}$ & 0.18 & 0.14 & 0.14 & 0.14 & 0.16 & 0.15 & 0.15 & 0.15 & 0.15 \\
\hline $\mathrm{MgO}$ & 1.90 & 1.62 & 1.35 & 2.00 & 2.25 & 2.35 & 2.12 & 2.25 & 2.43 \\
\hline $\mathrm{CaO}$ & 5.48 & 5.19 & 5.54 & 5.60 & 6.01 & 5.92 & 6.26 & 6.07 & 5.99 \\
\hline $\mathrm{Na}_{2} \mathrm{O}$ & 3.41 & 3.48 & 3.51 & 3.54 & 2.98 & 2.93 & 3.21 & 3.39 & 3.33 \\
\hline $\mathrm{K}_{2} \mathrm{O}$ & 1.65 & 1.67 & 1.76 & 1.62 & 1.57 & 1.50 & 1.52 & 1.56 & 1.53 \\
\hline $\mathrm{P}_{2} \mathrm{O}_{5}$ & 0.16 & 0.10 & - & 0.11 & 0.21 & 0.11 & - & 0.11 & 0.11 \\
\hline Total & 100 & 100 & 100 & 100 & 100 & 100 & 100 & 100 & 100 \\
\hline $\mathrm{Na}_{2} \mathrm{O}+\mathrm{K}_{2} \mathrm{O}$ & 5.05 & 5.15 & 5.27 & 5.15 & 4.55 & 4.42 & 4.73 & 4.95 & 4.86 \\
\hline $\mathrm{FeO}+\mathrm{MgO}$ & 7.22 & 6.41 & 5.53 & 7.26 & 7.88 & 8.46 & 8.27 & 8.10 & 8.54 \\
\hline
\end{tabular}

Total iron recalculated as $\mathrm{FeO}_{\text {tot }}$. Exp for experimental starting glass and Nat for natural composition (wet chemistry analysis and sample number after Boudon et al. 2017

\section{Methodology}

A brief review of the chosen samples, as well as the analytical and experimental methodology, is provided below. Further details are given in Supplementary Material SM1.

\section{Choice of the natural samples}

The Layou, Roseau and Grand Fond pumice samples used in this study come from the basal plinian fallout deposit of each eruption, which presents three advantages for the determination of pre-eruptive conditions. First, the base of the sequence represents the earliest erupted products, therefore the top part of the reservoir that is likely the less affected by potential magma recharge and magma mixing processes. Second, pumice samples ascended rapidly in the conduit and were rapidly quenched in air, so that syn- and post-eruptive processes that could modify magma chemistry, such as microlite crystallization, are minimized. Third, fallout pumice samples are not transported across long distances, thus post-eruptive chemical and mechanical contamination (entrapment of non-juvenile material, welding, deformation) is also minimized. Thus, the plinian pumice samples likely best represent the magma from the top part of the reservoir prior to eruption. Yet, where the plinian basal deposit was absent from the outcrop, the lowest part of the ignimbritic deposit was sampled, i.e. Grande Savane and Grand Bay.

The pumice samples were collected from the basal plinian fallout deposit of the eruptive sequence of Layou
(DOM41a3), Roseau (DOM60d1a) and Grand Fond (DOM43b), and from the main pumice flow deposit of Grande Savane (DOM40b) and Grand Bay (DOM31) (sample numbers as in Boudon et al. 2017; sampling locations in Fig. 1; whole-rock compositions in Table 1). For each eruptive sequence, the studied samples consisted of 6 to 10 pumices ( 2 to $6 \mathrm{~cm}$ in diameter) chosen from the single mode of the density distributions performed on 30 to 40 andesitic-dacitic pumices by Boudon et al. (2017).

\section{Sample analysis}

Both, natural and experimental, samples were analysed for phase identification using the backscattered-electron (BSE) signal of scanning electron microscopes (SEM; ZEISSSupra 55, ISTeP-UPMC, Paris; EDAX-Pegasus, ISTOBRGM, Orléans). Chemical analyses of the minerals and glasses were provided using electron microprobe (EMP; CAMECA-SX Five and CAMECA-SX100, CAMPARIS, Paris; CAMECA-SX Five, BRGM-ISTO, Orléans). The phase compositions for the natural samples are given in Table 2. The water contents of the experimental residual glasses were determined following the by-difference method using the EMP analyses and the glass standards in Balcone-Boissard et al. (2018). Phase proportions of the experimental charges were obtained by mass-balance calculations and compared to those obtained on natural samples by Boudon et al. (2017). 
Table 3 Experimental conditions and phase proportions

\begin{tabular}{|c|c|c|c|c|c|c|}
\hline Run \# & Sample & $X_{\mathrm{H} 2 \mathrm{Oin}}$ & Major phase (proportions in wt\%) & $\mathrm{Gl} /$ cryst (vol\%) & $\mathrm{H}_{2} \mathrm{O}_{\mathrm{m}}(\mathrm{wt} \%)$ & $\mathrm{H}_{2} \mathrm{O}_{\mathrm{c}}(\mathrm{wt} \%)$ \\
\hline \multicolumn{7}{|c|}{ Run $1,850^{\circ} \mathrm{C}, 275 \mathrm{MPa}, \sim \mathrm{NNO}+1,240 \mathrm{~h}$} \\
\hline $850-275-\mathrm{L} 1$ & LAY & 1 & $\mathrm{Gl}(73)+\operatorname{Plg}(12)+\operatorname{Amph}(13)+\operatorname{Mt}(2)$ & $77 / 23$ & 8.9 & 7.4 \\
\hline $850-275-\mathrm{L} 0.8$ & LAY & 0.78 & $\mathrm{Gl}(53)+\mathrm{Plg}(36)+\mathrm{Opx}(10)+\mathrm{Mt}(1)$ & $60 / 40$ & 6.2 & 5.8 \\
\hline $850-275-\mathrm{R} 1$ & ROS & 1 & $\mathrm{Gl}(75)+\mathrm{Plg}(11)+\operatorname{Amph}(11)+\mathrm{Mt}(3)$ & $74 / 26$ & 9.5 & 7.4 \\
\hline $850-275-\mathrm{R} 0.8$ & ROS & 0.78 & $\mathrm{Gl}(54)+\mathrm{Plg}(36)+\mathrm{Opx}(10)+\mathrm{Mt}(1)$ & $66 / 34$ & 6.7 & 5.8 \\
\hline \multicolumn{7}{|c|}{ Run $2,850^{\circ} \mathrm{C}, 190 \mathrm{MPa}, \sim \mathrm{NNO}+1,208 \mathrm{~h}$} \\
\hline $850-190-\mathrm{L} 1$ & LAY & 1 & $\mathrm{Gl}(73)+\mathrm{Plg}(17)+\mathrm{Opx}(7)+\mathrm{Mt}(3)$ & $71 / 29$ & 8.7 & 5.8 \\
\hline $850-190-\mathrm{L} 0.8$ & LAY & 0.76 & $\mathrm{Gl}+\mathrm{Plg}+\mathrm{Opx}+\mathrm{Mt}$ & $72 / 28$ & 6.4 & 4.4 \\
\hline $850-190-\mathrm{R} 1$ & ROS & 1 & $\mathrm{Gl}(72)+\mathrm{Plg}(18)+\mathrm{Opx}(7)+\mathrm{Mt}(3)$ & $62 / 38$ & 9.3 & 5.8 \\
\hline $850-190-\mathrm{R} 0.8$ & ROS & 0.81 & $\mathrm{Gl}(46)+\mathrm{Plg}(47)+\mathrm{Opx}(7)+\mathrm{Mt}(2)$ & $57 / 43$ & 6.2 & 4.7 \\
\hline \multicolumn{7}{|c|}{ Run $3,825^{\circ} \mathrm{C}, 285 \mathrm{MPa}, \sim \mathrm{NNO}+1,172 \mathrm{~h}$} \\
\hline 825-285-L1 & LAY & 1 & $\mathrm{Gl}(73)+\operatorname{Plg}(14)+\operatorname{Amph}(10)+\operatorname{Mt}(3)$ & $78 / 22$ & 8.4 & 7.6 \\
\hline $825-285-L 0.8$ & LAY & 0.80 & $\mathrm{Gl}(55)+\mathrm{Plg}(35)+\mathrm{Opx}(10)+\mathrm{Mt}(<1)$ & $55 / 45$ & - & 6.1 \\
\hline $825-285-\mathrm{R} 1$ & ROS & 1 & $\mathrm{Gl}(69)+\operatorname{Plg}(17)+\mathrm{Opx}(2)+\operatorname{Amph}(9)+\mathrm{Mt}(3)$ & $73 / 27$ & 9.1 & 7.6 \\
\hline $825-285-\mathrm{R} 0.8$ & ROS & 0.79 & $\mathrm{Gl}(59)+\mathrm{Plg}(30)+\mathrm{Opx}(10)+\mathrm{Mt}(1)$ & $56 / 44$ & - & 6.0 \\
\hline \multicolumn{7}{|c|}{ Run $4,825^{\circ} \mathrm{C}, 195 \mathrm{MPa}, \sim \mathrm{NNO}+1,242 \mathrm{~h}$} \\
\hline 825-195-L1 & LAY & 1 & $\mathrm{Gl}+\mathrm{Plg}+\mathrm{Opx}+\mathrm{Mt}$ & $71 / 29$ & 9.6 & 5.9 \\
\hline 825-195-L0.8 & LAY & 0.82 & $\mathrm{Gl}(54)+\mathrm{Plg}(36)+\mathrm{Opx}(8)+\mathrm{Mt}(1)+\operatorname{Ilm}(<1)$ & $60 / 40$ & - & 4.8 \\
\hline $825-195-\mathrm{R} 1$ & ROS & 1 & $\mathrm{Gl}+\mathrm{Plg}+\mathrm{Opx}+\mathrm{Mt}$ & $74 / 26$ & 8.7 & 5.9 \\
\hline $825-195-R 0.8$ & ROS & 0.78 & $\mathrm{Gl}+\mathrm{Plg}+\mathrm{Opx}+\mathrm{Mt}$ & $63 / 37$ & - & 4.6 \\
\hline \multicolumn{7}{|c|}{ Run $5,850^{\circ} \mathrm{C}, 375 \mathrm{MPa}, \sim \mathrm{NNO}+1,162 \mathrm{~h}$} \\
\hline $850-375-\mathrm{L} 1$ & LAY & 1 & $\mathrm{Gl}(74)+\operatorname{Plg}(9)+\operatorname{Amph}(14)+\operatorname{Mt}(3)$ & $78 / 22$ & 9.8 & 9.9 \\
\hline 850-375-L0.8 & LAY & 0.78 & $\mathrm{Gl}(62)+\mathrm{Plg}(25)+\operatorname{Amph}(7)+\mathrm{Opx}(5)+\mathrm{Mt}(1)$ & $68 / 32$ & 7.9 & 7.7 \\
\hline $850-375-\mathrm{R} 1$ & ROS & 1 & $\mathrm{Gl}(73)+\mathrm{Plg}(10)+\operatorname{Amph}(13)+\mathrm{Mt}(3)$ & $79 / 21$ & 9.2 & 9.9 \\
\hline $850-375-\mathrm{R} 0.8$ & ROS & 0.79 & $\mathrm{Gl}(58)+\operatorname{Plg}(30)+\mathrm{Opx}(10)+\mathrm{Mt}(1)+\operatorname{Ilm}(<1)$ & $67 / 33$ & 8.2 & 7.8 \\
\hline \multicolumn{7}{|c|}{ Run $6,850^{\circ} \mathrm{C}, 225 \mathrm{MPa}, \sim \mathrm{NNO}+1,190 \mathrm{~h}$} \\
\hline $850-225-\mathrm{L} 1$ & LAY & 1 & $\mathrm{Gl}(76)+\mathrm{Plg}(11)+\mathrm{Opx}(2)+\operatorname{Amph}(13)+\mathrm{Mt}(2)$ & $70 / 30$ & 8.6 & 6.7 \\
\hline 850-225-L0.9 & LAY & 0.89 & $\mathrm{Gl}(64)+\mathrm{Plg}(27)+\mathrm{Opx}(8)+\mathrm{Mt}(1)$ & $64 / 36$ & - & 6.0 \\
\hline $850-225-L 0.8$ & LAY & 0.81 & $\mathrm{Gl}(57)+\mathrm{Plg}(32)+\mathrm{Opx}(9)+\mathrm{Mt}(1)$ & $65 / 35$ & 5.7 & 5.4 \\
\hline $850-225-\mathrm{R} 1$ & ROS & 1 & $\mathrm{Gl}(73)+\mathrm{Plg}(15)+\mathrm{Opx}(5)+\mathrm{Amph}(5)+\mathrm{Mt}(2)$ & $76 / 24$ & 8.7 & 6.7 \\
\hline $850-225-\mathrm{R} 0.9$ & ROS & 0.89 & $\mathrm{Gl}(61)+\mathrm{Plg}(30)+\mathrm{Opx}(8)+\mathrm{Mt}(1)$ & $72 / 28$ & - & 6.0 \\
\hline $850-225-\mathrm{R} 0.8$ & ROS & 0.80 & $\mathrm{Gl}(62)+\mathrm{Plg}(28)+\mathrm{Opx}(9)+\mathrm{Mt}(1)+\mathrm{Ilm}$ & $67 / 33$ & - & 5.4 \\
\hline \multicolumn{7}{|c|}{ Run $7,900^{\circ} \mathrm{C}, 300 \mathrm{MPa}, \sim \mathrm{NNO}+1,190 \mathrm{~h}$} \\
\hline $900-300-\mathrm{L} 1$ & LAY & 1 & $\mathrm{Gl}(90)+\operatorname{Amph}(6)+\mathrm{Mt}(4)$ & $90 / 10$ & - & 7.7 \\
\hline 900-300-L0.8 & LAY & 0.80 & $\mathrm{Gl}(70)+\mathrm{Plg}(20)+\mathrm{Opx}(8)+\mathrm{Mt}(2)$ & $69 / 31$ & - & 6.2 \\
\hline $900-300-R 1$ & ROS & 1 & $\mathrm{Gl}(90)+\mathrm{Opx}(7)+\mathrm{Mt}(3)$ & $89 / 11$ & - & 7.7 \\
\hline 900-300-R0.8 & ROS & 0.82 & $\mathrm{Gl}(71)+\mathrm{Plg}(19)+\mathrm{Opx}(7)+\mathrm{Mt}(3)$ & $70 / 30$ & - & 6.3 \\
\hline \multicolumn{7}{|c|}{ Run $8,825^{\circ} \mathrm{C}, 400 \mathrm{MPa}, \sim \mathrm{NNO}+1,192 \mathrm{~h}$} \\
\hline $825-400-\mathrm{L} 1$ & LAY & 1 & $\mathrm{Gl}(77)+\operatorname{Plg}(11)+\operatorname{Amph}(10)+\operatorname{Mt}(2)$ & $77 / 23$ & - & 10.0 \\
\hline $825-400-\mathrm{L} 0.8$ & LAY & 0.80 & $\mathrm{Gl}(49)+\mathrm{Plg}(36)+\operatorname{Amph}(<1)+\mathrm{Opx}(13)+\mathrm{Mt}(<1)+\operatorname{Ilm}(1)$ & $56 / 44$ & - & 8.1 \\
\hline $825-400-\mathrm{R} 1$ & ROS & 1 & $\mathrm{Gl}(70)+\mathrm{Plg}(15)+\operatorname{Amph}(12)+\mathrm{Mt}(3)$ & $75 / 25$ & - & 10.1 \\
\hline $825-400-\mathrm{R} 0.8$ & ROS & 0.81 & $\mathrm{Gl}(51)+\mathrm{Plg}(34)+\mathrm{Opx}(14)+\mathrm{Mt}(<1)+\operatorname{Ilm}(1)$ & $51 / 49$ & - & 8.2 \\
\hline \multicolumn{7}{|c|}{ Run $9,875^{\circ} \mathrm{C}, 400 \mathrm{MPa}, \sim \mathrm{NNO}+1,215 \mathrm{~h}$} \\
\hline $875-400-\mathrm{L} 1$ & LAY & 1 & $\mathrm{Gl}(88)+\operatorname{Amph}(10)+\operatorname{Mt}(2)$ & $92 / 8$ & - & 9.9 \\
\hline $875-400-\mathrm{L} 0.8$ & LAY & 0.82 & $\mathrm{Gl}(72)+\mathrm{Plg}(18)+\operatorname{Amph}(5)+\mathrm{Opx}(3)+\mathrm{Mt}(2)$ & $75 / 25$ & - & 8.1 \\
\hline $875-400-\mathrm{R} 1$ & ROS & 1 & $\mathrm{Gl}(79)+\mathrm{Plg}(9)+\operatorname{Amph}(9)+\mathrm{Mt} .(3)$ & $83 / 17$ & - & 9.9 \\
\hline $875-400-\mathrm{R} 0.8$ & ROS & 0.78 & $\mathrm{Gl}(54)+\mathrm{Plg}(33)+\mathrm{Opx}(10)+\mathrm{Cpx}(1)+\mathrm{Mt}(1)+\mathrm{Ilm}(1)$ & $62 / 38$ & - & 7.7 \\
\hline \multicolumn{7}{|c|}{ Run $10,800{ }^{\circ} \mathrm{C}, 150 \mathrm{MPa}, \sim \mathrm{NNO}+2,120 \mathrm{~h}$} \\
\hline 800-150-GS1 & GS & 1 & $\mathrm{Gl}+\mathrm{Pl}+\mathrm{Amph}+\mathrm{Opx} ?+\mathrm{Mt}$ & $\sim 50$ & - & 5.1 \\
\hline $800-150-\mathrm{GB} 1$ & GB & 1 & $\mathrm{Gl}+\mathrm{Pl}+\mathrm{Amph} / \mathrm{Opx} ?+\mathrm{Mt}$ & $\sim 50$ & - & 5.1 \\
\hline
\end{tabular}

$\mathrm{X}_{\mathrm{H} 2 \mathrm{Oin}}=\mathrm{X}_{\mathrm{H} 2 \mathrm{O}} /\left(\mathrm{X}_{\mathrm{H} 2 \mathrm{O}}+\mathrm{X}_{\mathrm{CO} 2}\right)_{\text {initial. }}$ Gl glass, Plg plagioclase, Opx orthopyroxene, Cpx clinopyroxene, Amph amphibole, Mt titanomagnetite, Ilm ilmenite. Phase proportion calculated using mass balance calculation (where lacking Mt composition, one in the charge with the closest $P$ - $T$ - $X_{\mathrm{H} 2 \mathrm{O} \text { in }}$ conditions has been used) and determined by image analysis in vol\% (assuming area and volume proportion compares) with $\mathrm{Gl} / \mathrm{cryst}$ giving the volume proportion of glass over crystals. $\mathrm{H}_{2} \mathrm{O}_{\mathrm{m}}$ is melt $\mathrm{H}_{2} \mathrm{O}$ content (wt\%) determined by the EMP by-difference method and $\mathrm{H}_{2} \mathrm{O}_{\mathrm{c}}$ is melt $\mathrm{H}_{2} \mathrm{O}$ content calculated after the formulation of Newman and Lowenstern (2002)

clinopyroxene, $1-3 \%$ Fe-Ti oxides and 0-5\% amphibole (as traces in Grand Fond and Grand Bay, $<1 \%$ in Roseau and up to $5 \%$ in Layou and Grande Savane samples). Layou samples also show $<2 \%$ quartz as accessory mineral. Average compositions of the phenocrysts and glasses from the pumice samples are reported in Table 2.

\section{Plagioclase}

Core to rim compositional profiles were obtained for about 40 crystals of the different eruptions. Plagioclase often exhibits evidence for core resorption and marked oscillatory zoning (Fig. 2). Statistically speaking, three 


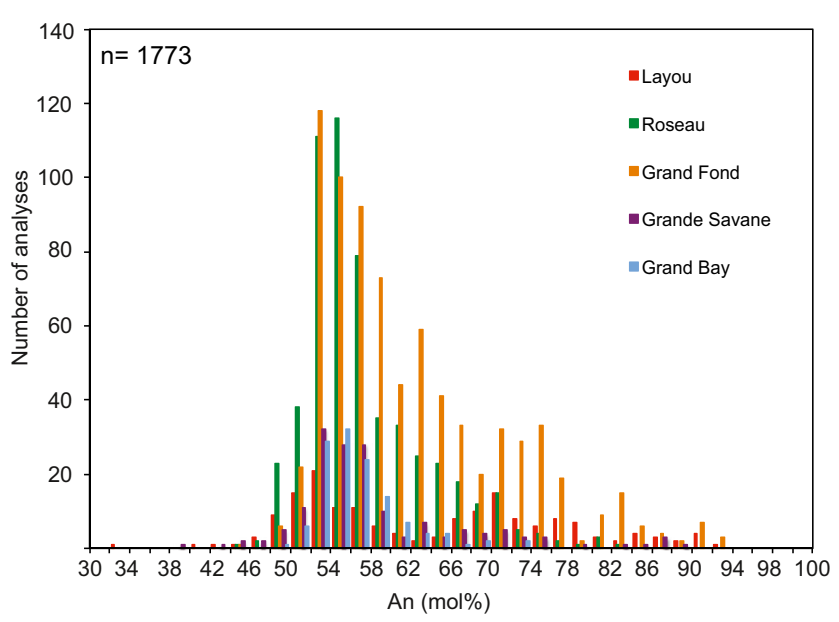

Fig. 3 Natural plagioclase compositions. Frequency histogram of chemical profiles in An mol\% from natural plagioclases in Layou, Roseau, Grand Fond, Grand Bay and Grande Savane deposits. Roseau (in green), Grand Fond (in orange), Grande Savane (in purple) and Grand Bay (in blue) crystals show a unimodal distribution (peak at $\mathrm{An}_{53-55}$ ), whereas Layou (in red) crystals have a bimodal distribution (peaks at $\mathrm{An}_{50-55}$ and $\mathrm{An}_{68-70}$ )

\section{Orthopyroxene}

Orthopyroxenes are hypersthenes with a large compositional range between $\mathrm{En}_{47}$ and $\mathrm{En}_{63}$ (Howe et al. 2014; Solaro 2017). Whereas $\sim 15-20 \%$ of the orthopyroxenes show compositional zonings (either reverse, normal or multiple), most of them $(\sim 80-85 \%)$ are unzoned, so that their compositions may be considered as representative of the pre-eruptive conditions in the reservoir (Solaro 2017). Unzoned crystals have compositions that slightly differ among eruptions: $\mathrm{En}_{49-50}$ for Grande Savane, $\mathrm{En}_{50-52}$ for Layou, $\mathrm{En}_{52-53}$ for Roseau and Grand Bay and $\mathrm{En}_{54-56}$ for Grand Fond samples (Table 2).

\section{Clinopyroxene}

In Roseau, Layou and Grand Bay samples, clinopyroxenes are diopsides, with $\mathrm{Wo}_{44-45}$ and $\mathrm{En}_{37-38}$ whatever the eruption considered (Table 2). Samples show Mg\# between 0.61 and 0.71, with a broad peak at 0.68 . Most of the Roseau, Layou and Grand Bay clinopyroxenes, and all of those (rare) clinopyroxenes present in Grand Fond and Grande Savane samples show strong evidence of resorption (marked by orthopyroxene overgrowths) suggesting that they are likely antecrysts.

\section{Fe-Ti oxides}

In the five studied ignimbritic deposits, Fe-Ti oxides comprise both titanomagnetites and ilmenites (Table 2). Titanomagnetites show compositions with $\sim 75-80 \mathrm{wt} \%$ $\mathrm{FeO}_{\text {tot }}$ and $\sim 10 \mathrm{wt} \% \mathrm{TiO}_{2}\left(\mathrm{Mag}_{71-75}\right.$, calculated after Sauerzapf et al. 2008). Ilmenites contain $\sim 48 \mathrm{wt} \% \mathrm{FeO}_{\text {tot }}$ and $\sim 45 \mathrm{wt} \% \mathrm{TiO}_{2}\left(\mathrm{Ilm}_{83-87}\right.$, calculated after Sauerzapf et al. 2008). The Fe-Ti oxides in Layou samples $\left(\mathrm{Mag}_{72-74}\right.$ and $\mathrm{Ilm}_{85-86}$, on average) suggest slightly more reduced conditions of crystallization than for the Roseau pumice ( $\mathrm{Mag}_{73}$ 75 and $\mathrm{Ilm}_{84-85}$, on average).
Fig. 4 Selected profiles of amphiboles in Layou basal Plinian pumice, showing variations in $\mathbf{a} \mathrm{Al}_{2} \mathrm{O}_{3}$ content and b $\mathrm{Mg} \#=\mathrm{Mg} /\left(\mathrm{Mg}+\mathrm{Fe}_{\mathrm{tot}}\right)$. The BSE images of two of the amphiboles in which profiles were performed highlight crystal growth zonation of different compositions

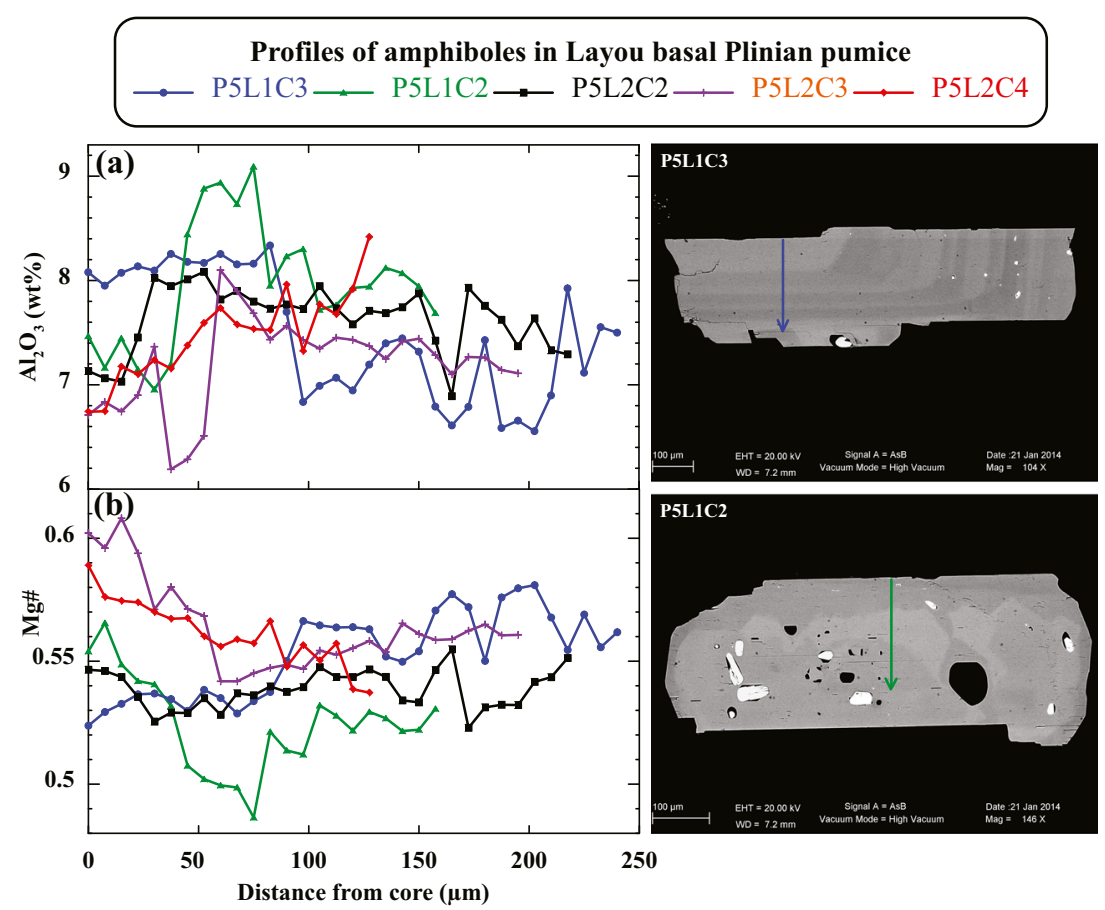


Fig. 6 Natural and experimental glass compositions of Roseau (left) and Layou (right) samples, presented as (in wt \%) $\mathrm{SiO}_{2}$ vs.

$\mathrm{Mg \#}, \mathrm{Al}_{2} \mathrm{O}_{3}, \mathrm{CaO}$, and $\mathrm{K}_{2} \mathrm{O}$.

Labels correspond to the starting glass composition (L for LAY and $\mathrm{R}$ for ROS) with $X_{\mathrm{H} 2 \mathrm{Oin}}$ (1 or 0.8; respective fields delimited by dashed lines) as in Table 3. The compositions of the natural residual glasses (grey box), glass inclusions (dot box) and Grande Savane glasses (yellow dashed box), are represented for comparison; natural data from BalconeBoissard et al. (2018)

\section{Experiments}

\section{Glasses}

X Starting glasses

$\nabla 875^{\circ} \mathrm{C}-400 \mathrm{MPa}$

$850^{\circ} \mathrm{C}-375 \mathrm{MPa}$

$\star 825^{\circ} \mathrm{C}-400 \mathrm{MPa}$ $900^{\circ} \mathrm{C}-300 \mathrm{MPa}$

$850^{\circ} \mathrm{C}-275 \mathrm{MPa}$

$\triangle 825^{\circ} \mathrm{C}-285 \mathrm{MPa}$ $850^{\circ} \mathrm{C}-225 \mathrm{MPa}$

$\triangle 850^{\circ} \mathrm{C}-190 \mathrm{MPa}$

$825^{\circ} \mathrm{C}-195 \mathrm{MPa}$

$\diamond 800^{\circ} \mathrm{C}-150 \mathrm{MPa}$
Natural

$\odot$ Bulk rocks

$\square$ Residual glasses

$\because$ Glass inclusions

$\square$ Grande Savane (all glasses)

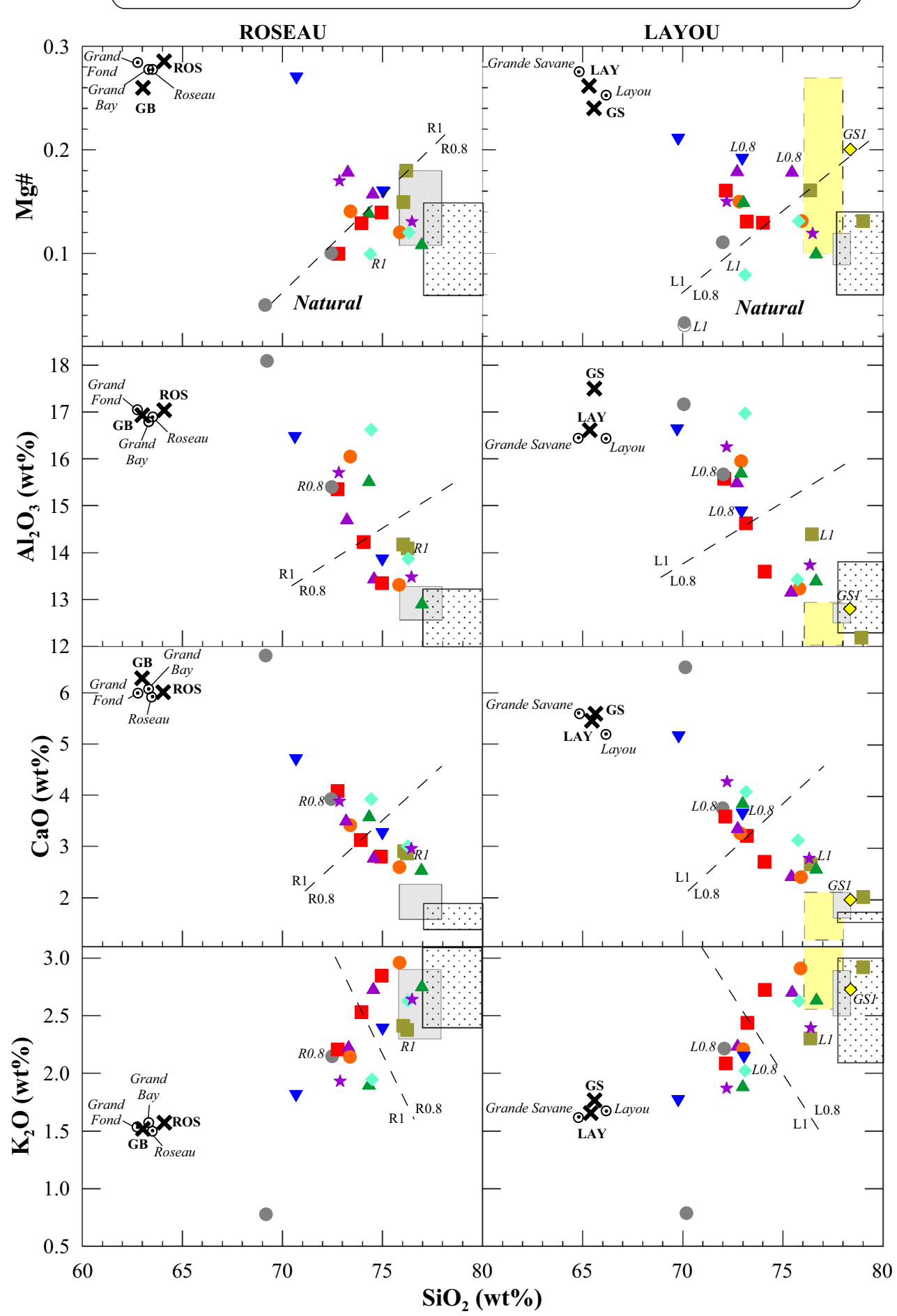


with the redox sensor, although the calculated $T$ is underestimated by about $60{ }^{\circ} \mathrm{C}$ (SM2A). In Grand Fond and Grand Bay (Roseau-like) samples, neighbouring titanomagnetites and ilmenites that passed the chemical equilibrium test of Bacon and Hirschmann (1988) give $T$ of $\sim 855-860{ }^{\circ} \mathrm{C}$ and a $f_{\mathrm{O} 2}$ of $\mathrm{NNO}+0.6$ to +0.7 . Layou Fe-Ti oxides suggest a slightly lower $T$ of $\sim 820^{\circ} \mathrm{C}$ for a $f_{\mathrm{O} 2}$ of NNO +0.6 (SM2A), in agreement with the $\sim 720-820{ }^{\circ} \mathrm{C}$ range determined in Layou ignimbritic deposits (Howe et al. 2014).

The crystallization $T$ may be calculated from amphibole composition using the formulation of Ridolfi and Renzulli (2012) which, as validated by Erdmann et al. (2014), mostly returns reliable $T$ values. When applied to the natural amphiboles with 6-7 wt $\% \mathrm{Al}_{2} \mathrm{O}_{3}$, the calculation suggests $T$ from 774 to $809^{\circ} \mathrm{C}$ and a $f_{\mathrm{O} 2}$ of $\sim \mathrm{NNO}+1$ (SM2B). For the Layou amphiboles with $\sim 9 \mathrm{wt} \% \mathrm{Al}_{2} \mathrm{O}_{3}$, the calculated $T$ is $\sim 827^{\circ} \mathrm{C}$ and the $f_{\mathrm{O} 2}$ is $\sim \mathrm{NNO}+0.7$ (SM2B), which is about $20-50{ }^{\circ} \mathrm{C}$ higher and slightly more reduced than calculated for the $6-$ $7 \mathrm{wt} \% \mathrm{Al}_{2} \mathrm{O}_{3}$-bearing amphibole.

Another means of estimating crystallization $T$ is to use the orthopyroxene-melt geothermometer of Putirka (2008), based on the Fe-Mg partitioning between orthopyroxene and melt. Couples of equilibrated orthopyroxenes and glass inclusions (partition coefficient $K_{\mathrm{D}}=0.29 \pm 0.06$; Putirka 2008; $K_{\mathrm{D}}$ confirmed by the present experiments) return $850-860{ }^{\circ} \mathrm{C}$ for Layou samples, in agreement with $T$ retrieved from $\mathrm{Fe}-\mathrm{Ti}$ oxides, and $870-890^{\circ} \mathrm{C}$ for Roseau and Grand Fond samples (SM2C). These values fall in the range of $800-940{ }^{\circ} \mathrm{C}$ determined on (low $\mathrm{Mg \# )}$ orthopyroxene-melt couples in ignimbritic samples from Dominica Island by Howe et al. (2015).

Crystallization $T$ can be calculated from plagioclase-melt equilibrium, which strongly depends on melt $\mathrm{H}_{2} \mathrm{O}$ content (Putirka 2008; Waters and Lange 2015). The model of Waters and Lange (2015) is applicable to conditions of $\mathrm{H}_{2} \mathrm{O}$ saturation in fluids and $\mathrm{H}_{2} \mathrm{O}$ contents $<8.3 \mathrm{wt} \%$. Results roughly agree with the run $T$, but tend to overestimate $T$ by at most $30{ }^{\circ} \mathrm{C}$ for $\mathrm{H}_{2} \mathrm{O}$ contents $\sim 5.0 \mathrm{wt} \%$, whereas underestimating $T$ by up to $45{ }^{\circ} \mathrm{C}$ for $\mathrm{H}_{2} \mathrm{O}$ contents $7.5 \mathrm{wt} \%$ (SM2D). Calculated $T$ for Layou or Roseau samples (plagioclase rim and melt inclusions or residual glass) suggest $T$ of $\sim 780^{\circ} \mathrm{C}$ for melt $\mathrm{H}_{2} \mathrm{O}$ content of 7.6-7.8 wt\% (maximum $\mathrm{H}_{2} \mathrm{O}$ contents of orthopyroxene-hosted glass inclusions) and $T$ of $\sim 820{ }^{\circ} \mathrm{C}$ for melt $\mathrm{H}_{2} \mathrm{O}$ content of $6.5 \mathrm{wt} \%$ (maximum $\mathrm{H}_{2} \mathrm{O}$ contents of plagioclase-hosted glass inclusions).

\section{Pressure}

Although $P$ may be retrieved from amphibole composition (Ridolfi and Renzulli 2012; Erdmann et al. 2014), tests using the experimental amphiboles yielded poor agreement between run and calculated pressures (with calculated pressures underestimating experimental ones by $\sim 100 \mathrm{MPa}$; SM2B).

$P$ may be retrieved directly from the volatile contents of the glass inclusions, assuming that the melt was trapped in the magma chamber and did not suffer significant postentrapment crystallization or volatile loss. From the glass inclusions trapped in orthopyroxenes and using the $\mathrm{H}_{2} \mathrm{O}-\mathrm{CO}_{2}$ solubility model of Newman and Lowenstern (2002) for rhyolitic liquids at $850^{\circ} \mathrm{C}$, Balcone-Boissard et al. (2018) suggest $P$ from 250 to $350 \mathrm{MPa}$ for the Layou samples, 200 to $300 \mathrm{MPa}$ for the Roseau samples (with a single value suggesting a entrapment pressure of $150 \mathrm{MPa}$ ) and 160 to $270 \mathrm{MPa}$ for the Grand Fond samples (with a single inclusion suggesting an entrapment pressure of $750 \mathrm{MPa}$ ). Glass inclusions trapped in plagioclase phenocrysts systematically suggest lower entrapment pressures. The high pressures deduced from the $\mathrm{H}_{2} \mathrm{O}-\mathrm{CO}_{2}$ contents of the glass inclusions in orthopyroxenes and plagioclases are in agreement with those deduced from the $\mathrm{H}_{2} \mathrm{O}$-chlorine data, i.e. $\geq 200 \mathrm{MPa}$ (Balcone-Boissard et al. 2018). Such a pressure range is also in good agreement with the range of 200-350 MPa calculated from multiple-reaction geobarometry on Dominica crustal xenoliths (Ziberna et al. 2017).

\section{Summary}

The pre-eruptive storage conditions deduced from the petrological study of the natural pumice samples suggest for Roseau magma: $T$ from 780 to $890{ }^{\circ} \mathrm{C}, f_{\mathrm{O} 2}$ from $\mathrm{NNO}+0.6$ to +1.0 , up to $7.5 \mathrm{wt} \% \mathrm{H}_{2} \mathrm{O}$ dissolved in melt and $P$ of $\sim$ $350 \mathrm{MPa}$. For Layou magma, we have $T$ from $\sim 775$ to $860{ }^{\circ} \mathrm{C}, f_{\mathrm{O} 2} \sim \mathrm{NNO}+0.6$, up to $7.6 \mathrm{wt} \% \mathrm{H}_{2} \mathrm{O}$ dissolved in melt and $P$ of $\sim 350 \mathrm{MPa}$. In order to confirm such exceptional magma storage conditions in the Antilles arc and contribute to the general issue of how large magma bodies survive cooling and become eruptible, a set of phase-equilibrium experiments is presented below.

\section{Phase equilibria}

The aim of the phase equilibria was to define crystallization conditions that first reproduced the Layou samples. That is, $30 \pm 5 \mathrm{wt} \%$ phenocrysts consisting of $\mathrm{An}_{50-54}, \mathrm{En}_{50-52}$, amphibole with 6-7 wt\% of $\mathrm{Al}_{2} \mathrm{O}_{3}$ (hereafter referred as to $\mathrm{Am}_{6-}$ 7), $\mathrm{Mag}_{72-74}, \mathrm{Ilm}_{85-86}$ and minor quartz, coexisting with 77$80 \mathrm{wt} \% \mathrm{SiO}_{2}$ residual liquid $\left(\mathrm{Liq}_{77-80}\right)$. The experiments were also run to define the Roseau sample conditions, i.e. $30 \pm$ $5 \mathrm{wt} \%$ phenocrysts consisting of $\mathrm{An}_{53-58}, \mathrm{En}_{52-53}, \mathrm{Mag}_{73-75}$ and $\mathrm{Ilm}_{84-85}$, coexisting with $\mathrm{Liq}_{76-77}$. Amphibole (strongly resorbed) and clinopyroxene are assumed to be unstable in the top of the Roseau reservoir. 


\section{Phase relationships and proportions}

In the $\mathrm{H}_{2} \mathrm{O}$-saturated charges (Fig. 7a, c), the crystallization sequence for decreasing $P$ - $T$ conditions is magnetite (liquidus phase), plagioclase and orthopyroxene, the last two appearing at slightly higher $P-T$ conditions in ROS than in LAY. Amphibole is stable in a field above $150 \mathrm{MPa} / 800{ }^{\circ} \mathrm{C}$ and $300 \mathrm{MPa} / 875^{\circ} \mathrm{C}$. Ilmenite was not found.

In the $\mathrm{H}_{2} \mathrm{O}$-undersaturated charges (Fig. 7b, d), titanomagnetite, ilmenite, plagioclase and orthopyroxene are ubiquitous for both compositions for the investigated $P-T$ conditions. For $X_{\mathrm{H} 2 \mathrm{Oin}} \sim 0.8$, the major difference between LAY and ROS comes from amphibole that is stable in LAY at $P>300 \mathrm{MPa}$ (Fig. 7b), whereas it is absent in ROS (Fig. 7d). Clinopyroxene may be present in ROS at $400 \mathrm{MPa}$ and $875^{\circ} \mathrm{C}$. Quartz did not crystallize.

Total crystallinities range from $\sim 10 \mathrm{wt} \%$ at high $\mathrm{H}_{2} \mathrm{O}$ contents and high $T$ to $\sim 50 \mathrm{wt} \%$ at low $\mathrm{H}_{2} \mathrm{O}$ contents and low $T$. Crystallinities deduced from mass balance calculations and image analysis are in broad agreement, differing on average by less than $\pm 5 \%$, exceptionally $10-12 \%$ in a few charges (Table 3).

\section{Phase compositions}

The experimental phase compositions are given in Supplementary material SM3. Magnetites are $\mathrm{Mag}_{76-83}$ in the $\mathrm{H}_{2} \mathrm{O}$-saturated charges and $\mathrm{Mag}_{65-76}$ in the $\mathrm{H}_{2} \mathrm{O}$-undersaturated charges. Ilmenites from the $\mathrm{H}_{2} \mathrm{O}$-undersaturated charges are $\mathrm{Ilm}_{81-89}$ (SM3A).

Plagioclase covers a wide compositional range from $\mathrm{An}_{87}$ to $\mathrm{An}_{52-54}$ (Fig. 7; SM3B). This confirms previous conclusions on the strong influence of melt $\mathrm{H}_{2} \mathrm{O}$ content and $T$ on its composition (Martel et al. 1999; Fig. 8).

Orthopyroxene is hypersthene ranging from $\mathrm{En}_{43}$ to $\mathrm{En}_{68}$ (Fig. 7; SM3C). Its composition is known to be strongly dependent on $f_{\mathrm{O} 2}$ (Martel et al. 1999), but since $f_{\mathrm{O} 2}$ was kept approximately constant in our experiments, its compositional variation is mainly attributed to changes in $P-T-\mathrm{H}_{2} \mathrm{O}$ conditions. Indeed, a $T$ increase from 825 to $875^{\circ} \mathrm{C}$ at constant $\mathrm{H}_{2} \mathrm{O}$ content and $P(300$ or $400 \mathrm{MPa})$ increases the En content by 10-15 mol\% (Fig. 8). The effect of total $P$ at constant $\mathrm{H}_{2} \mathrm{O}$ content is also remarkable: for $\sim 6 \mathrm{wt} \% \mathrm{H}_{2} \mathrm{O}$ at $850{ }^{\circ} \mathrm{C}$, En in orthopyroxene decreases from $\mathrm{En}_{66}, \mathrm{En}_{57}$ to $\mathrm{En}_{52}$ with increasing $P$ from 200, 250, to $300 \mathrm{MPa}$ (Fig. 8a). In contrast, at $850{ }^{\circ} \mathrm{C}$ and $250 \mathrm{MPa}$, En increases from $\mathrm{En}_{54}, \mathrm{En}_{57}$ to $\mathrm{En}_{62}$ with melt $\mathrm{H}_{2} \mathrm{O}$ contents increasing from 5.5, 6.0 to $6.8 \mathrm{wt} \%$ (Fig. 8a).

Amphibole is a hornblende with $44-49$ wt $\% \mathrm{SiO}_{2}, 8$ 12 wt $\% \mathrm{Al}_{2} \mathrm{O}_{3}, 9-11 \mathrm{wt} \% \mathrm{CaO}, 11-16 \mathrm{wt} \% \mathrm{FeO}$ and $11-$ 15 wt\% MgO (SM3D). Fe-Mg and Al-Si amphibole-melt $\mathrm{K}_{\mathrm{D}}$ are $0.13 \pm 0.04$ (calculated with total $\mathrm{Fe}$ as $\mathrm{FeO}$ ) and $0.95 \pm 0.06$, respectively, in agreement with previous studies on similar magma compositions (Martel et al. 1999; Pichavant et al. 2002). For given $P$ - $T$ conditions, amphibole in $\mathrm{H}_{2} \mathrm{O}-$ saturated samples has higher Mg\# than in the $\mathrm{H}_{2} \mathrm{O}$-undersaturated samples, consistent with their slightly higher $f_{\mathrm{O} 2}$ (Fig. 5b).

Experimental glass is dacitic to rhyolitic, with $69-79 \mathrm{wt} \%$ $\mathrm{SiO}_{2}, 12-18 \mathrm{wt} \% \mathrm{Al}_{2} \mathrm{O}_{3}, 2-7 \mathrm{wt} \% \mathrm{CaO}$ and $1-3 \mathrm{wt} \% \mathrm{~K}_{2} \mathrm{O}$ (Fig. 6; SM3E). The glass $\mathrm{H}_{2} \mathrm{O}$ content ranges from $5.7 \mathrm{wt} \%$ at $200 \mathrm{MPa}$ to $9.8 \mathrm{wt} \%$ at $375 \mathrm{MPa}$ (estimated with the bydifference method; SM1), mostly in agreement (within $1.5 \mathrm{wt} \%$ ) with $\mathrm{H}_{2} \mathrm{O}$ contents calculated for a rhyolitic melt using the formulation of Newman and Lowenstern (2002).

\section{Discussion}

\section{Pre-eruptive storage conditions of Dominica magmas}

\section{Roseau-like compositional group}

The Roseau Plinian pumice consists of $30 \pm 5 \%$ phenocrysts with $22 \% \mathrm{An}_{53-55}$ plagioclase, 1-5\% $\mathrm{En}_{52-53}$ orthopyroxene, $1-3 \% \mathrm{Mag}_{72-75}$ and $\mathrm{Ilm}_{84}$. This phase assemblage was experimentally reproduced below $\sim 875^{\circ} \mathrm{C}$ at $250 \mathrm{MPa}$ (Fig. 7c) for $\mathrm{H}_{2} \mathrm{O}$-saturated conditions and below $875{ }^{\circ} \mathrm{C}$ at $400 \mathrm{MPa}$ for $\mathrm{H}_{2} \mathrm{O}$-undersaturated conditions (Fig. 7d). $\mathrm{H}_{2} \mathrm{O}$-saturated conditions can be ruled out since neither experimental plagioclase $\left(\sim \mathrm{An}_{75}\right.$ at $\left.850{ }^{\circ} \mathrm{C}, 375 \mathrm{MPa}\right)$ nor orthopyroxene $\left(>\mathrm{En}_{57}\right.$ at $850{ }^{\circ} \mathrm{C}, \sim 200 \mathrm{MPa}$ ) match natural phenocryst rim compositions. The experiments that best reproduce Roseau pumice phenocrysts are those performed around $400 \mathrm{MPa}, 850{ }^{\circ} \mathrm{C}$ and for $X_{\mathrm{H} 2 \mathrm{Oin}} \sim 0.8$ (Fig. $7 \mathrm{~b}$ ). These conditions also allow the natural residual glass compositions (75.5-78.0 wt $\%$ $\mathrm{SiO}_{2}$ ) to be broadly reproduced despite $\mathrm{Al}_{2} \mathrm{O}_{3}$ and $\mathrm{CaO}$ being slightly overestimated (by $1 \mathrm{wt} \%$; Fig. 6) and plagioclase modes being higher in the experiment $\left(30 \%\right.$ at $850{ }^{\circ} \mathrm{C}$, $375 \mathrm{MPa}$ ) than in pumice $(22 \%)$. Therefore, best estimates for the pre-eruptive conditions of the Roseau magma include a pressure of $\sim 400 \mathrm{MPa}$ (equivalent to a depth of $\sim 16 \mathrm{~km}$ considering a rock density of $2.45 \mathrm{~g} / \mathrm{cm}^{3}$ ), a temperature of $850{ }^{\circ} \mathrm{C}$, a $f_{\mathrm{O} 2}$ of $\mathrm{NNO}+1$ and a melt $\mathrm{H}_{2} \mathrm{O}$ content of $\sim 7-$ $8 \mathrm{wt} \%$. These results agree with the $T-f_{\mathrm{O} 2}$ data calculated from $\mathrm{Fe}-\mathrm{Ti}$ oxides pairs in Grand Fond samples (Roseau-like compositional group) and with the highest $\mathrm{H}_{2} \mathrm{O}$ contents measured in the orthopyroxene-hosted glass inclusions (BalconeBoissard et al. 2018).

The mismatch noted above for $\mathrm{Al}_{2} \mathrm{O}_{3}$ and $\mathrm{CaO}$ between experimental and natural residual glasses is most probably due to a small compositional difference between the starting ROS sample and the reactive magma (i.e. the subsystem at chemical equilibrium under the pre-eruptive conditions, Pichavant et al. 2007; SM1). It is likely that the bulk ROS is slightly too high in $\mathrm{Al}_{2} \mathrm{O}_{3}$ and $\mathrm{CaO}$ than the reactive magma 
However, $\mathrm{H}_{2} \mathrm{O}$-saturated conditions are not appropriate for the Layou pre-eruptive magma. At $800{ }^{\circ} \mathrm{C}$ and $150 \mathrm{MPa} \mathrm{H}_{2} \mathrm{O}-$ saturated, the natural plagioclase composition is reproduced but the crystallinity $(\sim 50 \%)$ is higher than expected $(\sim 30 \%)$ and the amphibole is too high in $\mathrm{Al}_{2} \mathrm{O}_{3}(12 \mathrm{wt} \%)$. There is also a mismatch concerning magnetite (too $\mathrm{TiO}_{2}$-poor), a consequence of a highly oxidizing experimental $f_{\mathrm{O} 2}(\sim \mathrm{NNO}+2$; Fig. 7a). At $850{ }^{\circ} \mathrm{C}$ and $225 \mathrm{MPa} \mathrm{H}_{2} \mathrm{O}$-saturated, the correct crystallinity is obtained but both plagioclase and orthopyroxene have An and En contents higher by $\geq$ $10 \mathrm{~mol} \%$ than the corresponding phenocrysts. In comparison, the $\mathrm{H}_{2} \mathrm{O}$-undersaturated run at $850{ }^{\circ} \mathrm{C}$ and $375 \mathrm{MPa}$ is very close to reproduce the natural samples. It crystallizes $25 \mathrm{wt} \% \mathrm{An}_{53}, 7 \mathrm{wt} \% \mathrm{Am}_{10}, 5 \mathrm{wt} \% \mathrm{En}_{50}$ and $<1 \mathrm{wt} \%$ $\operatorname{Mag}_{74}$ (Fig. 7b; Table 3). Clinopyroxene is absent, in agreement with the natural phase assemblage. Therefore, the main part of the Layou magma likely crystallized at 350-400 $\mathrm{MPa}$ (equivalent to a depth of $\sim 14-16 \mathrm{~km}$ ) and $\sim 850{ }^{\circ} \mathrm{C}$, under a $f_{\mathrm{O} 2}$ of $\mathrm{NNO}+0.6$, and with a melt $\mathrm{H}_{2} \mathrm{O}$ content of $\sim 7.5-$ $8.0 \mathrm{wt} \%$. These conditions agree with the $T-f_{\mathrm{O} 2}$ deduced from the $\mathrm{Am}_{9-10}$ compositions and the orthopyroxene-liquid thermometer (SM2B-C) and with the $\sim 7.5 \mathrm{wt} \% \mathrm{H}_{2} \mathrm{O}$ contents of the orthopyroxene-hosted glass inclusions (Balcone-Boissard et al. 2018).

Nevertheless, the Layou experimental charges and natural products differ in important three main aspects. First, amphibole is a minor but characteristic phase in Layou deposits, stable in a much larger domain in the LAY than in the ROS composition (Fig. 7). Yet, our experimental amphiboles do not reproduce well the compositions of amphibole phenocrysts (Fig. 5). Amphiboles with 9-10 wt\% $\mathrm{Al}_{2} \mathrm{O}_{3}$ (Am $9-10$; corresponding to cores) have been experimentally synthesized (e.g. at $400 \mathrm{MPa}, 825$ and $875^{\circ} \mathrm{C}$ ) but they have $\mathrm{Mg \#}$ significantly higher than the natural crystals, as most experimental amphiboles, and compositions corresponding to $\mathrm{Am}_{6-7} \mathrm{rims}$ (Fig. 4a) have not been reproduced. Experimental amphiboles plot along a broadly positive $\mathrm{Al}_{2} \mathrm{O}_{3}$ vs. $\mathrm{Mg \#}$ trend that contrasts with the well-defined negative correlation shown by the phenocrysts (Fig. 5). Only one experimental amphibole (at $375 \mathrm{MPa}, 850{ }^{\circ} \mathrm{C}$ ) plots in the natural amphibole field (Fig. 5). To complement our experiments and refine the crystallization conditions for Layou amphiboles, additional experimental constraints from the literature have been used. The main conclusions are twofold. First, that $\mathrm{Am}_{6-7}$ can crystallize from a rhyolitic/granitic magma with $\sim 72 \mathrm{wt} \% \quad \mathrm{SiO}_{2}$ (Dall'agnol et al. 1999) and Am A-10 $_{9}$ from a dacitic magma with 65-68 wt\% $\mathrm{SiO}_{2}$ (e.g. sample\# 875-400-L1 in SM3D; Scaillet and Evans 1999; Cadoux et al. 2014). Second, the high- $\mathrm{Al}_{2} \mathrm{O}_{3}$ low-Mg\# end of the Layou natural amphibole field requires more reduced conditions than the $f_{\mathrm{O} 2}$ range imposed in this study, being well reproduced by $<$ NNO experiments on Santorini rhyodacites (Cadoux et al. 2014). In comparison, the low $-\mathrm{Al}_{2} \mathrm{O}_{3}$ high- $\mathrm{Mg \#}$ end of the trend is compatible with redox conditions between $\mathrm{NNO}$ and NNO +1 , suggesting that additional LAY experiments at $<825^{\circ} \mathrm{C}$ could produce amphiboles in this part of the array. To summarize, the Layou natural amphibole array reflects mixing between two amphibole end-member populations present in the plumbing system, one $\left(\mathrm{Am}_{9-10}\right)$ corresponding to a phase crystallizing from dacitic magmas under relatively reduced conditions and the other $\left(\mathrm{Am}_{6-7}\right)$ to a crystallization product of rhyolitic magmas under "average" $f_{\mathrm{O} 2}$ conditions. Independent evidence for parts of the Layou magma storage zone being relatively reduced comes from the $T-f_{\mathrm{O} 2}$ data which include a group of data points clustered at NNO to NNO-0.2 (Howe et al. 2014).

Second, quartz occurs as euhedral crystals in Layou deposits, whereas it has not been found in our experiments. Yet, quartz is known to saturate during the crystallization of intermediate bulk compositions such as the Taupo dacite (Conrad et al. 1988), the Pinatubo dacite (Scaillet and Evans 1999; Prouteau and Scaillet 2003) and the Unzen dacite (Holtz et al. 2005). For a constant (dacitic) bulk composition, quartz saturation depends on three variables (which also control the $\mathrm{SiO}_{2}$ content of the melt at saturation): temperature, melt $\mathrm{H}_{2} \mathrm{O}$ content and pressure. Between 200 and $400 \mathrm{MPa}$, quartz saturates at temperatures from $\sim 775^{\circ} \mathrm{C}$ to up to $950{ }^{\circ} \mathrm{C}$, for $<4$ to $\sim 8 \mathrm{wt} \% \mathrm{H}_{2} \mathrm{O}$ in the melt; melt $\mathrm{SiO}_{2}$ contents at saturation range from 71 to a maximum of $76-77 \mathrm{wt} \%$, being positively correlated with $\mathrm{H}_{2} \mathrm{O}$ and inversely correlated with temperature (Scaillet and Evans 1999; Prouteau and Scaillet 2003; Holtz et al. 2005). For melt $\mathrm{H}_{2} \mathrm{O}$ concentrations as in Dominica magmas (6-8 $\mathrm{wt} \%)$, quartz saturation would be expected for $76-77 \mathrm{wt} \% \mathrm{SiO}_{2}$ in the melt, i.e. in the same range as our most evolved experimental liquids (Fig. 6). Therefore, the most $\mathrm{SiO}_{2}$-rich melts generated from the crystallization of ROS and LAY are quartz-undersaturated (since quartz is lacking in experimental charges) but evolve near quartz saturation. It is most likely that additional experiments at temperatures lower than investigated $\left(<800^{\circ} \mathrm{C}\right.$ ?) would lead to the appearance of quartz in experimental phase assemblages. We therefore interpret the presence of quartz crystals in the Layou deposit as evidence for parts of the magma plumbing system being slightly colder $\left(<800{ }^{\circ} \mathrm{C}\right.$ ) $)$ than the main magma body $(\sim$ $850^{\circ} \mathrm{C}$ ). This conclusion is consistent with the dispersion in the $T-f_{\mathrm{O} 2}$ data for Layou and the presence of a group of points at $\sim 780{ }^{\circ} \mathrm{C}$ (Howe et al. 2014).

Third, Layou residual glasses are slightly more $\mathrm{SiO}_{2}$-rich than Roseau (77.5-78.5 vs. 75.5-78 wt\%), all being less silicic than glass inclusions which, for both Roseau and Layou, reach up to $80 \mathrm{wt} \% \mathrm{SiO}_{2}$ (Fig. 6). In both systems, compositions of inclusions are outside the range of experimental preeruptive melts. The slightly higher silica content in Layou than in Roseau residual glasses is consistent with the presence of quartz crystals which imposes quartz saturation in Layou residual melts. Glass inclusions have $\mathrm{SiO}_{2}$ concentrations that 
extend to beyond quartz saturation, whether defined from experiments (76-77 $\mathrm{wt} \% \mathrm{SiO}_{2}$, see above) or by the Layou quartz-saturated residual glasses $\left(77.5-78.5 \mathrm{wt} \% \mathrm{SiO}_{2}\right)$. Liquids above the quartz saturation threshold must be considered as metastable (they should crystallize quartz to equilibrate their $\mathrm{SiO}_{2}$ concentration) if brought under conditions defined above for pre-eruptive magma storage. Alternatively, these liquids could reflect equilibration at pressures much lower than the pre-eruptive range (350-400 MPa) because decreasing pressure shifts quartz saturation towards higher melt $\mathrm{SiO}_{2}$ contents. Last, the fact that glass inclusion compositions vary with the host crystal indicates local compositional control, most probably by crystallization and dissolution reactions involving the trapped liquid and the host crystal. We conclude that no direct relation can be established between glass inclusion major-element compositions and pre-eruptive liquids.

The prime implication of the complexities recognized above for the Layou magma is that some parts of the storage zone evolved under conditions significantly different from the main magma body $\left(\sim 850{ }^{\circ} \mathrm{C}, 350-400 \mathrm{MPa}, \sim \mathrm{NNO}+0.6\right.$ and $\sim 7.5-8.0 \mathrm{wt} \% \mathrm{H}_{2} \mathrm{O}$ in the melt). In particular, the $\mathrm{Am}_{6-}$ 7 rims around $\mathrm{Am}_{9-10}$ cores, the presence of a few $\mathrm{An}_{40-50}$ rims around plagioclases and the occurrence of quartz suggest that some portions of the magma body underwent further cooling and differentiation. Although data are lacking to constrain the crystallization conditions of those magma batches, cooling down to $\sim 780{ }^{\circ} \mathrm{C}$ would be consistent with the presence of quartz, the Fe-Ti oxide $T-f_{\mathrm{O} 2}$ data (Howe et al. 2014) and amphibole thermometry (lower $T$ for $\mathrm{Am}_{6-7}$ than for $\mathrm{Am}_{9-10}$; $\left.\mathrm{SM} 2 \mathrm{~A}-\mathrm{B}\right)$, whereas a $f_{\mathrm{O} 2}$ of $\sim \mathrm{NNO}+1$ is suggested by $\mathrm{Mg \#}$ in $\mathrm{Am}_{6-7}$ and $\mathrm{Am}_{6-7}$ oximetry (Fig. 5b and SM2B). Cooling-induced differentiation of the Layou dacitic magma could have led to the segregation of rhyolitic $\left(\sim 72 \mathrm{wt} \% \mathrm{SiO}_{2}\right)$ magma batches from which the $\mathrm{Am}_{6-7}$ and $<\mathrm{An}_{50}$ co-crystallized. There is no clear evidence to constrain the $\mathrm{H}_{2} \mathrm{O}$ content and crystallization $P$ for these magma pockets, but coolinginduced differentiation is more likely to have occurred above the top of the main reservoir (i.e. $\leq 350-400 \mathrm{MPa}$ ). Furthermore, the destabilized $\mathrm{Am}_{6-7}$ in the Roseau Plinian pumice could be inherited from similar differentiated magma parts. Another interesting aspect of the Layou data is the evidence from amphibole compositions $\left(\mathrm{Am}_{9-10}\right)$ of the presence of a reduced component in the magma storage region. Reduced volcanic rocks are very rare in the Lesser Antilles but 8.5 Ma-old fayalite-ferroaugite dacites, rhyodacites and rhyolites are known on St Lucia (Le Guen de Kerneizon et al. 1982). They evolved under a $f_{\mathrm{O} 2}$ significantly $<\mathrm{NNO}$ as estimated from compositions of titanomagnetite phenocrysts and using the Ti vs. Mg\# plot of Martel et al. (1999).

The recent results of Boudon et al. (2017) suggest that the Grande Savane and Layou ignimbrites were emitted from the same eruptive centre (Morne Diablotins; Fig. 1). Indeed,
Grande Savane and Layou rocks share similar major (Table 1; Fig. 6) and trace-element bulk-rock compositions (Boudon et al. 2017), and they carry the same phenocryst assemblage with significant amounts of amphibole. The Grande Savane glasses (either glass inclusions or residual glasses) and the Layou residual glasses overlap, although the former are slightly less differentiated (76-78 wt $\% \mathrm{SiO}_{2}$ ) than the latter (Fig. 6). Yet, in terms of phenocryst compositions, the Grande Savane and Layou pumice samples are different. As for amphibole, the Grande Savane pumice samples contain the largest amounts ( $5-10 \%$ vs. $1-5 \%$ in Layou samples) and the largest crystals (up to $1 \mathrm{~mm}$ vs. $\sim 200 \mu \mathrm{m}$ in Layou samples). Compositions are the most depleted in $\mathrm{Al}_{2} \mathrm{O}_{3}$ (5.5 wt\%) and they lack the $\mathrm{Am}_{9-10}$ group found in Layou. Plagioclases in Grande Savane have $\sim \mathrm{An}_{40}$ rims which could have crystallized at equilibrium with $\mathrm{Am}_{6}$ amphiboles (Dall'agnol et al. 1999) and $\mathrm{En}_{49-50}$ orthopyroxenes (n.b., $\mathrm{En}_{52-53}$ in Layou; Table 2). Although $\mathrm{H}_{2} \mathrm{O}$ contents are lacking for the Grande Savane magma, the glass inclusions (six in orthopyroxenes, one in ilmenite and one in amphibole; Table 2) have electron microprobe major-element totals of $94 \mathrm{wt} \%$, which precludes volatile contents higher than $6 \mathrm{wt} \%$ (i.e. higher than the $\mathrm{H}_{2} \mathrm{O}$ solubility at 150-200 MPa). Therefore, in comparison with the Layou main magma, the Grande Savane magma is interpreted to have crystallized at shallow pressure, possibly $\sim 150-200 \mathrm{MPa}$ as suggested by the glass inclusions and consistent with the lack of Am9-10. The phenocryst assemblage and in particular the presence of abundant $\mathrm{Am}_{5-6}$ in the Grande Savane samples suggests crystallization from a more evolved and colder batch than the main Layou magma.

\section{Structure of the magmatic system beneath Dominica}

The results above suggest a magmatic system located as deep as $\sim 16 \mathrm{~km}(\sim 400 \mathrm{MPa})$ beneath Dominica and active over the last 62 ky (Fig. 9b). Although two different magma compositions (amphibole-free andesitic-dacitic magma for the Roseau-like group and amphibole-bearing dacitic magma for the Layou-like group) were involved, the respective magma chemistries are consistent with the Layou-like group being a differentiation product of the Roseau-like group, thus favouring the hypothesis of common parental magmas (Gavrilenko et al. 2016). The plumbing system could have the form of either a single magma storage region or independent magma bodies. More differentiated individual magma batches have been identified as indicated by the results for Layou and Grande Savane. These can be viewed as coming from cooler margins of the same large body (Layou) or as different parts of a plumbing system with a significant vertical extension (Grande Savane). In the case of Grande Savane, it is possible to consider an upper segregated magma pocket that ponded at the mid-crustal discontinuity. 
Fig. 9 Schematic section of the crust below Dominica. a $\mathrm{P}$ wave velocity $(V p)$ structure beneath the Lesser Antilles arc, modified from Melekhova et al. (2019).

The $V p$ of $6.0 \mathrm{~km} / \mathrm{s}$ outline the upper crust, $6.8 \mathrm{~km} / \mathrm{s}$ delimit the middle crust and $7.8 \mathrm{~km} / \mathrm{s}$ outline the lower crust, the basis of which marks the Moho discontinuity with the upper mantle. Below Dominica, the mid-crust discontinuity is located at $\sim 16-18 \mathrm{~km}$ in depth, where the ignimbritic reservoirs have been experimentally located (red box). b Storage conditions of Dominica dacitic magmas determined in this study; the main magma ponds at the mid-crust discontinuity $(\sim 16 \mathrm{~km}$ deep), either as a common or individual reservoirs, with vertical extensions of more differentiated magma batches; the subscript linked to $\mathrm{Am}$ gives the $\mathrm{Al}_{2} \mathrm{O}_{3}$ wt $\%$ of the amphibole (a)

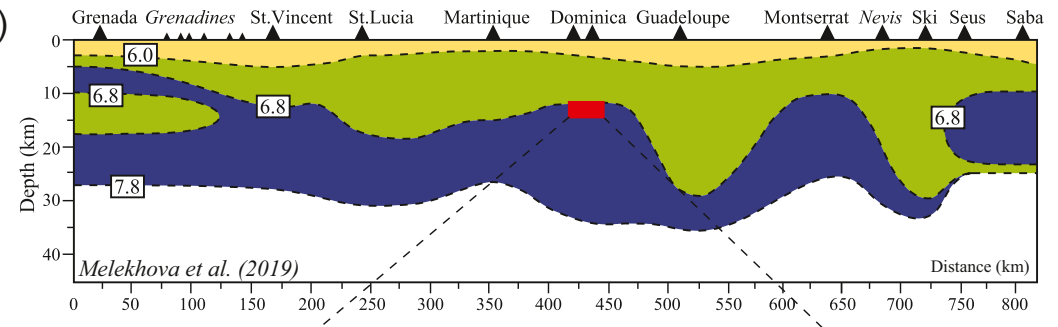

(b)

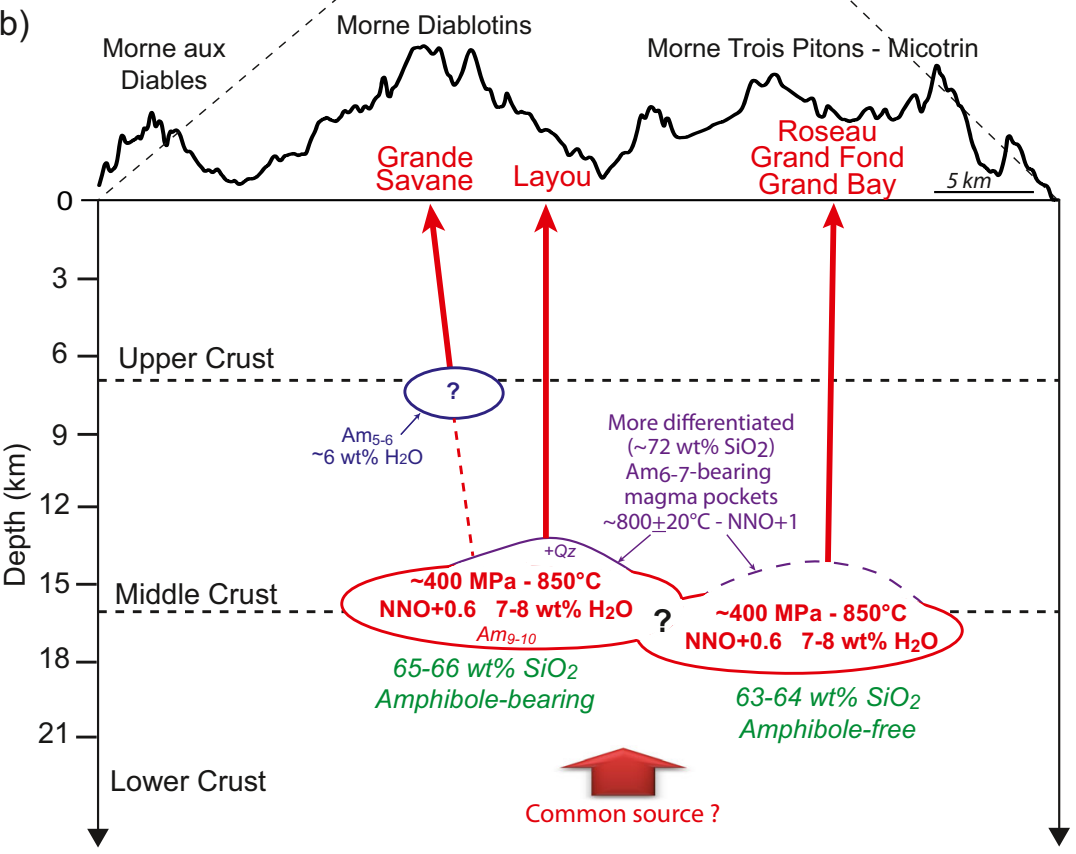

Kopp et al. (2011) acquired seismic data across the volcanic arc North of Dominica (where the Tiburon Ridge subducts obliquely beneath the fore-arc) and, by a tomographic inversion, proposed a structural model of the arc crust consisting in three distinct layers: a 3-km-thick upper crust of volcanogenic sedimentary rocks and volcanoclastics, underlain by an intermediate to felsic middle crust and a plutonic mafic (gabbros) lower crust. These results are confirmed and extended to the whole active arc by a recent reconstruction of the crustal structure using an inversion approach combining petrology of magmatic crustal xenoliths and seismic receiver functions (Fig. 9a; Melekhova et al. 2019). Both studies agree that the mid-crustal discontinuity beneath Dominica is located at $\sim 13-16 \mathrm{~km}$, i.e. in the same range as the magma reservoir depth determined from our experimental study. The mid-crustal discontinuity likely corresponds to a structural, mechanical and physical (density) discontinuity that could favour magma ponding.

Ignimbritic eruptions of very large volumes (> $100 \mathrm{~km}^{3}$ ) are associated with collapse-caldera structures (e.g. Kos Plateau Tuff, Greece, Allen 2001; Taupo, New Zealand, Houghton et al. 1995). So far, no caldera has been identified in Dominica (Boudon et al. 2017), but the erupted volumes are $<10 \mathrm{~km}^{3}$. Yet, erupted volumes of this order of magnitude often lead to caldera-forming eruptions, such as Krakatau 1883 (Indonesia; $12.5 \mathrm{~km}^{3}$ ) or Pinatubo 1991 (Philippines; $\sim 2.2 \mathrm{~km}^{3}$ ). The difference between Dominica and these calderaforming eruptions is the depth of magma storage. Indeed, the caldera-forming eruptions of Krakatau or Pinatubo involved magmas stored in the upper crust $(\leq$ $200 \mathrm{MPa}$; Mandeville et al. 1996; Scaillet and Evans 1999), whereas we find a middle-lower crust storage level ( $400 \mathrm{MPa})$ below Dominica. Collapse-caldera development is likely controlled by the relationships between the chamber aspect ratio, defined as the ratio between magma chamber depth and width, and the volume fraction of erupted magma (Geyer et al. 2006). The reservoirs in Dominica are about $16 \mathrm{~km}$ deep and $5 \mathrm{~km}^{3}$, so that the chamber aspect ratio ranges between $\sim 15$ for a spherical chamber and $\sim 3$ for sill-type reservoirs. Assuming partial emptying and reservoir volumes two or three times larger than the erupted products would keep aspect ratios greater than one. The combination of magma volumes < $10 \mathrm{~km}^{3}$ and chamber aspect ratios $>1$ has been demonstrated to prevent collapse-caldera forming (Geyer et al. 2006; Marti et al. 2008). 


\section{Comparison with magma storage conditions on the neighbouring islands}

The other islands along the Lesser Antilles arc (Martinique, Guadeloupe, Montserrat) are characterized by a single active eruptive centre (at least during the recent period of activity) frequently emitting deposits of small volumes, generally < $0.5 \mathrm{~km}^{3}$ and exceptionally $\sim 1 \mathrm{~km}^{3}$. Magma storage conditions for some recent eruptions on these islands have been determined experimentally via phase-equilibrium studies. In Montserrat, the andesitic magma $\left(\sim 59 \mathrm{wt} \% \mathrm{SiO}_{2}\right)$ of the ongoing eruption of Soufriere Hills was found to be stored at $820-840{ }^{\circ} \mathrm{C}, \sim 130 \mathrm{MPa}(<5 \mathrm{~km}$ depth$)$ and $\sim \Delta \mathrm{NNO}+1$ with $4.3 \pm 0.5 \mathrm{wt} \% \mathrm{H}_{2} \mathrm{O}$ in the melt (Barclay et al. 1998). In Guadeloupe, the andesitic magma $\left(\sim 60 \mathrm{wt} \% \mathrm{SiO}_{2}\right)$ from the $1530 \mathrm{AD}$ sub-plinian eruption of La Soufrière was stored at $875^{\circ} \mathrm{C}, \sim 175 \mathrm{MPa}$ and $\sim \Delta \mathrm{NNO}+0.5$ to +1 , with $\sim 5.5 \mathrm{wt} \%$ $\mathrm{H}_{2} \mathrm{O}$ in the melt (Pichavant et al. 2018). In Martinique, historical eruptions of Montagne Pelée, either plinian fallout or lava dome-forming, were fed by an andesitic magma ( $61 \mathrm{wt} \%$ $\mathrm{SiO}_{2}$ ) stored at $875-900{ }^{\circ} \mathrm{C}, \sim 200 \mathrm{MPa}(\sim 6 \mathrm{~km}$ depth $)$ and $\sim \Delta \mathrm{NNO}+0.4$ to +0.8 , with $\sim 6 \mathrm{wt} \% \mathrm{H}_{2} \mathrm{O}$ in the melt (Martel et al. 1998).

These studies show that the small-volume andesitic eruptions considered were fed by magmas stored in a similar range of conditions in terms of temperature $\left(850-900{ }^{\circ} \mathrm{C}\right)$, pressure (175-200 MPa), $f_{\mathrm{O} 2}(\sim \Delta \mathrm{NNO}+1)$ and melt $\mathrm{H}_{2} \mathrm{O}$ contents (close to saturation). In comparison, Dominica constitutes an anomaly in the Lesser Antilles arc for four reasons. First, larger volumes were erupted $\left(\sim 5 \mathrm{~km}^{3}\right.$ DRE/eruption; Boudon et al. 2017). Second, magmas were dominantly evolved (dacites with 63-66 wt $\% \mathrm{SiO}_{2}$ ). Third, magmas were stored at higher pressures $(\sim 400 \mathrm{MPa})$ with higher melt $\mathrm{H}_{2} \mathrm{O}$ contents (7-8 wt \%). Fourth, eruptions are much less frequent so that the magma repose times are longer than for the volcanic systems from the other islands.

Larger volumes of erupted magma in Dominica with respect to the neighbouring islands may result from particularities in the subduction geometry (Wadge and Shepherd 1984; Macdonald et al. 2000), from the presence of oceanic fractures zones near subduction favouring water supply to the mantle wedge (Manea et al. 2014; Schlaphorst et al. 2016) or from a fault system that potentially create a structural context with a strong extensional component beneath Dominica (Feuillet et al. 2010) thus fostering lateral expansion of the reservoirs and making possible the storage of large magma volumes. These hypotheses could explain the accumulation of large magma volumes but not the unusual depths of the reservoirs beneath Dominica. Large-volume eruptions do not necessarily require deep magma storage, as found at the Aegean Arc or the Taupo Volcanic Zone where magmas are stored within the upper crust ( $\leq 200 \mathrm{MPa}$; Bachmann et al. 2010; Bégué et al. 2014). At the Antilles arc, one explanation for the voluminous storage region in Dominica being deeper than the ones on the neighbouring volcanic islands could be an along-arc fluctuation of the crustal structure. Indeed, previous seismic refraction studies suggested significant differences in the crust thickness, with the thickest one being under Dominica (up to $37 \mathrm{~km}$; Melekhova et al. 2019) and in the depth of the middlelower crust interface, with variations from 2 to $20 \mathrm{~km}$ (Boynton et al. 1979; Macdonald et al. 2000; Melekhova et al. 2019). However, this mid-crustal discontinuity could be at similar depth below Martinique, Montserrat and Dominica (Fig. 9a; Melekhova et al. 2019). As a result, the storage depth below Dominica must be attributed to other reasons, such as slab dehydration related to the fracture zone near Dominica or peculiar magma productivity where the crust is the thickest.

As an alternative to this regional model, it is worth remembering that the upper crustal reservoirs identified below Martinique, Guadeloupe and Montserrat are shallow (uppercrustal interface) expressions of complex magmatic systems that extend deeper in the crust. For Montagne Pelée, there is petrological evidence for a deep ( $400 \mathrm{MPa})$ basaltic andesite reservoir that differentiates through fractional crystallization to feed the upper crustal andesitic reservoir (Pichavant et al. 2002). For La Soufrière of Guadeloupe, the 1530 AD eruption was triggered by the recharge of a deep basaltic magma into a shallow resident andesitic body (Pichavant et al, 2018). At Montserrat, the involvement of mafic magmas of deep origin is attested by the presence of enclaves in the present-day eruption products (Plail et al. 2014). Therefore, the presence of igneous bodies at mid-crustal levels seems well established in the Lesser Antilles arc, so that the interesting point in Dominica is not so the presence of deep magma storage zones but the scarcity of upper-crustal reservoirs during the period of large-volume eruptions (24-51 ka; except maybe for the Grande Savane ignimbrite). The rarity of shallow reservoirs prevents frequent drainage of the deep igneous bodies (contrary to evidence on the neighbouring islands), thus favours deep and long-lasting accumulation of large magma volumes that can differentiate to dacitic compositions. Thus, magma accumulation rates below Dominica would neither be particularly high nor different from the other islands, but would reflect longer timescales of magma storage.

\section{Conclusions}

Combining a petrological study of basal plinian deposits of the main ignimbritic eruptions in Dominica with crystallization experiments suggests that the dacitic magmas were mainly stored at $\sim 400 \mathrm{MPa}(\sim 16 \mathrm{~km}$ depth $), \sim 850{ }^{\circ} \mathrm{C}$ and contained 7-8 wt $\% \mathrm{H}_{2} \mathrm{O}$ dissolved in melt. This storage depth is consistent with magma ponding at the mid-crustal discontinuity beneath Dominica. More differentiated magma batches 
have been identified, possibly reflecting a plumbing system with a significant vertical extension.

With respect to the volcanic centres on the neighbouring islands (Martinique, Guadeloupe, Montserrat), the larger volumes of Dominica eruptions may result from a geodynamic context that locally favours extensional components and magma accumulation. Over the time period of the large eruptions in Dominica, upper-crustal reservoirs seem to be rare enough to prevent frequent drainage of the deep (mid-crust) main magma body. This gives time for growth of large magma chambers and differentiation at Dominica. Therefore, high magma fluxes (i.e. flare-up) may not be a necessary condition for large-volume ignimbritic eruptions in Dominica.

We conclude that the primary magma reservoirs feeding Dominica ignimbritic eruptions are deeper than those feeding other volcanic systems along the arc, and that reservoir depth can explain both the absence of calderas on the island, as well as the unusually large volumes of these events. Linking depths of magma storage to crust structure and regional tectonic setting may be a key point to the general understanding of the generation of large-volume pumice eruptions of arc volcanoes.

Acknowledgements We would like to thank Michel Fialin and Nicolas Rividi (service CAMPARIS) and Ida di Carlo (ISTO) for assistance during microprobe analyses and Omar Boudouma (SEM, Sorbonne Université) for help during SEM imaging. We thank Vincent Christmann who started the study during his master's thesis. We are grateful to the reviewers, Jenny Riker, Maxim Gavrilenko, Elena Melekhova, the Associate Editor, Maxim Portnyagin and the Executive Editor, Andrew Harris, for their comments that significantly improved the manuscript. This work was financially supported by the French MNRT doctoral grant (to C. Solaro), the European FP7_VUELCO project (J. Gottsmann, PI; grant 282759) and the French INSU Action Incitative (G. Boudon, PI).

\section{References}

Allen SR (2001) Reconstruction of a major caldera-forming eruption from pyroclastic deposit characteristics: Kos Plateau Tuff, eastern Aegean Sea. J Volcanol Geotherm Res 105(1):141-162

Andújar J, Scaillet B, Pichavant M, Druitt TH (2016) Generation conditions of Dacite and Rhyodacite via the crystallization of an andesitic magma. Implications for the plumbing system at Santorini (Greece) and the origin of tholeiitic or Calc-alkaline differentiation trends in arc magmas. J Petrol 57(10):1887-1920

Annen C (2009) From plutons to magma chambers: thermal constraints on the accumulation of eruptible silicic magma in the upper crust. Earth Planet Sci Lett 284(3):409-416

Annen C, Sparks RSJ (2002) Effects of repetitive emplacement of basaltic intrusions on thermal evolution and melt generation in the crust. Earth Planet Sci Lett 203(3):937-955

Bachmann O, Wallace PJ, Bourquin J (2010) The melt inclusion record from the rhyolitic Kos Plateau Tuff (Aegean arc). Contrib Mineral Petrol 159(2):187-202
Bacon CR, Hirschmann MM (1988) Mg/Mn partitioning as a test for equilibrium between coexisting Fe-Ti oxides. Am Mineral 73(12):57-61

Balcone-Boissard H, Boudon G, Blundy JD, Martel C, Brooker RA, Deloule E, Solaro C, Matjuschkin V (2018) Deep pre-eruptive storage of silicic magmas feeding Plinian and dome-forming eruptions of central and northern Dominica (Lesser Antilles) inferred from volatile contents of melt inclusions. Contrib Mineral Petrol 173:101

Barclay J, Rutherford MJ, Carroll MR, Murphy MD, Devine JD, Gardner J, Sparks RSJ (1998) Experimental phase equilibria constraints on pre-eruptive storage conditions of the Soufrière Hills magma. Geophys Res Lett 25(18):3437-3440

Bégué F, Gualda GA, Ghiorso MS, Pamukcu AS, Kennedy BM, Gravley DM, Chambefort I (2014) Phase-equilibrium geobarometers for silicic rocks based on rhyolite-MELTS. Part 2: application to Taupo Volcanic Zone rhyolites. Contrib Mineral Petrol 168(5):1082

Boudon G, Balcone-Boissard H, Solaro C, Martel C (2017) Revised chronostratigraphy of recurrent ignimbritic eruptions in Dominica (Lesser Antilles Arc): implications on the behavior of the magma plumbing system. J Volcanol Geotherm Res 343:135-154

Bouysse P, Westercamp D (1990) Subduction of Atlantic aseismic ridges and Late Cenozoic evolution of the Lesser Antilles island arc. Tectonophysics 175(4):349357-355380

Boynton CH, Westbrook GK, Bott MHP, Long RE (1979) A seismic refraction investigation of crustal structure beneath the Lesser Antilles island arc. Geophys J Int 58(2):371-393

Cadoux A, Scaillet B, Druitt TH, Deloule E (2014) Magma storage conditions of large Plinian eruptions of Santorini volcano (Greece). J Petrol 55:1129-1171

Carazzo G, Tait S, Kaminski E, Gardner JE (2012) The recent Plinian explosive activity of Mt. Pelée volcano (Lesser Antilles): the P1 AD 1300 eruption. Bull Volcanol 74:2187-2203

Carey SN, Sigurdsson H (1980) The Roseau ash: deep-sea tephra deposits from a major eruption on Dominica, Lesser Antilles arc. J Volcanol Geotherm Res 7(1-2):67-86

Conrad WK, Nicholls IA, Wall VJ (1988) Water-saturated and Undersaturated melting of Metaluminous and Peraluminous crustal compositions at $10 \mathrm{~kb}$ : evidence for the origin of silicic magmas in the Taupo volcanic zone, New Zealand, and other occurrences. J Petrol 29(4):765-803

Costa F, Scaillet B, Pichavant M (2004) Petrological and experimental constraints on the pre-eruption conditions of Holocene Dacite from Volcan San Pedro (36 S, Chilean Andes) and the importance of Sulphur in silicic subduction-related magmas. J Petrol 45(4):855881

Dall'Agnol R, Scaillet B, Pichavant M (1999) An experimental study of a lower proterozoic A-type granite from the Eastern Amazonian Craton, Brazil. J Petrol 40:1673-1698

De Silva S (2008) Arc magmatism, calderas, and supervolcanoes. Geology 36(8):671-672

De Silva SL, Gosnold WD (2007) Episodic construction of batholiths: insights from the spatiotemporal development of an ignimbrite flareup. J Volcanol Geotherm Res 167(1):320-335

Degruyter W, Huber C (2014) A model for eruption frequency of upper crustal silicic magma chambers. Earth Planet Sci Lett 403:117-130

Degruyter W, Huber C, Bachmann O, Cooper KM, Kent AJ (2016) Magma reservoir response to transient recharge events: the case of Santorini volcano (Greece). Geology 44(1):23-26

Di Napoli R, Aiuppa A, Allard P (2014) First multi-gas based characterization of the boiling Lake volcanic gas (Dominica, Lesser Antilles). Ann Geophys 56:S0559

Druitt TH, Mellors RA, Pyle DM, Sparks RSJ (1989) Explosive volcanism on Santorini, Greece. Geol Mag 126(2):95-126

Erdmann S, Martel C, Pichavant M, Kushnir ARL (2014) Amphibole as an archivist of magmatic crystallization conditions: problems, potential, and implications for inferring magma storage prior to the 
paroxysmal 2010 eruption of Mount Merapi, Indonesia. Contrib Mineral Petrol 167:1016-1039

Feuillet N, Leclerc F, Tapponnier P, Beauducel F, Boudon G, Le Friant A, Deplus C, Lebrun JF, Nercessian A, Saurel JM, Clément V (2010) Active faulting induced by slip partitioning in Montserrat and link with volcanic activity: New insights from the 2009 GWADASEIS marine cruise data. Geophys Res Lett 37. https://doi.org/10.1029/ 2010GL042556

Fournier N, Witham F, Moreau-Fournier M, Bardou L (2009) Boiling lake of Dominica West Indies: high-temperature volcanic crater lake dynamics. J Geophys Res Solid Earth 114. https://doi.org/10.1029/ 2008JB005773

Gardner JE, Rutherford MJ, Carey S, Sigurdsson H (1995) Experimental constraints on pre-eruptive water contents and changing magma storage prior to explosive eruptions of Mount St. Helens volcano. Bull Volcanol 57:1-17

Gavrilenko M, Ozerov A, Kyle P, Carr MJ, Nikulin A, Vidito C, Danyushevsky L (2016) Abrupt transition from fractional crystallization to magma mixing at Gorely volcano (Kamchatka) after caldera collapse. Bull Volcanol 78(7):1-28

Geyer A, Folch A, Marti J (2006) Relationship between caldera collapse and magma chamber withdrawal: an experimental approach. J Volcanol Geotherm Res 157:375-386

Ghiorso MS, Evans BW (2008) Thermodynamics of rhombohedral oxide solid solutions and a revision of the Fe-Ti two-oxide geothermometer and oxygen-barometer. Am J Sci 308(9):957-1039

Hammer JE, Rutherford MJ, Hildreth W (2002) Magma storage prior to the 1912 eruption at Novarupta, Alaska. Contrib Mineral Petrol 144(2):144-162

Heiken G, McCoy FJ (1984) Caldera development during the Minoan eruption, Thira, Cyclades, Greece. J Geophys Res 89(B10):84418462

Holtz F, Sato H, Lewis J, Behrens H, Nakada S (2005) Experimental petrology of the 1991-1995 Unzen dacite, Japan. Part I: phase relations, phase composition and pre-eruptive conditions. J Petrol 46(2): 319-337

Houghton BF, Wilson CJN, McWilliams MO, Lanphere MA, Weaver SD, Briggs RM, Pringle MS (1995) Chronology and dynamics of a large silicic magmatic system: Central Taupo volcanic zone, New Zealand. Geology 23:13-16

Howe TM, Lindsay JM, Shane P, Schmitt AK, Stockli DF (2014) Reevaluation of the Roseau tuff eruptive sequence and other ignimbrites in Dominica, Lesser Antilles. J Quatern Sci 29(6):531-546

Howe TM, Lindsay JM, Shane P (2015) Evolution of young andesiticdacitic magmatic systems beneath Dominica, Lesser Antilles. J Volcanol Geotherm Res 297:69-88

Jellinek AM, De Paolo DJ (2003) A model for the origin of large silicic magma chambers: precursors of caldera-forming eruptions. Bull Volcanol 65:363-381

Kopp H, Weinzierl W, Becel A, Charvis P, Evain M, Flueh ER, Klaeschen D (2011) Deep structure of the central Lesser Antilles Island arc: relevance for the formation of continental crust. Earth Planet Sci Lett 304(1):121-134

Le Guen de Kerneizon M, Carron JP, Maury R, Bellon H, Dupuy C (1982) Rhyolites with fayalite and ferroaugite in Saint-Lucia, Lesser Antilles island arc. Bull Mineral 105(2):203-211

Lindsay JM, Stasiuk M, Shepherd J (2003) Geological history and potential hazards of the late-Pleistocene to recent plat pays volcanic complex, Dominica, Lesser Antilles. Bull Volcanol 65(2):201-220

Lindsay JM, Robertson R, Shepherd B, Ali S (eds) (2005a) Volcanic Hazard Atlas of the Lesser Antilles. Seismic Res Center, St Augustine, Trinidad and Tobago. Univ West Indies, $279 \mathrm{p}$

Lindsay JM, Trumbull RB, Siebel W (2005b) Geochemistry and petrogenesis of late Pleistocene to recent volcanism in southern Dominica, Lesser Antilles. J Volcanol Geotherm Res 148:253-294
Lipman PW (2007) Incremental assembly and prolonged consolidation of cordilleran magma chambers: evidence from the southern Rocky Mountain volcanic field. Geosphere 3(1):42-70

Luhr J (1990) Experimental phase relations of water and sulfur saturated arc magmas and the 1982 eruptions of El Chichon volcano. J Petrol 31:1071-1114

Macdonald R, Hawkesworth CJ, Heath E (2000) The Lesser Antilles volcanic chain: a study in arc magmatism. Earth Sci Rev 49(1-4): $1-76$

Mandeville CW, Carey S, Sigurdsson H (1996) Magma mixing, fractional crystallization and volatile degassing during the 1883 eruption of Krakatau volcano, Indonesia. J Volcanol Geotherm Res 74:243-274

Manea VC, Leeman WP, Gerya T, Manea M, Zhu G (2014) Subduction of fracture zones controls mantle melting and geochemical signature above slabs. Nature Commun 5

Martel C, Pichavant M, Bourdier JL, Traineau H, Holtz F, Scaillet B (1998) Magma storage conditions and control of eruption regime in silicic volcanoes: experimental evidence from Mt Pelée. Earth Planet Sci Lett 156:89-99

Martel C, Pichavant M, Holtz F, Scaillet B, Bourdier J-L, Traineau H (1999) Effect of $\mathrm{fO}_{2}$ and $\mathrm{H}_{2} \mathrm{O}$ on andesite phase relations between 2 and 4 kbar. J Geophys Res 104(B12):29453-29470

Martel C, Champallier R, Prouteau G, Pichavant M, Arbaret L, BalconeBoissard H, Boudon G, Boivin P, Bourdier JL, Scaillet B (2013) Phase relations in trachytes and implication for magma storage conditions in the Chaîne des Puys (French Massif Central). J Petrol 54(6):1071-1107

Marti J, Geyer A, Folch A, Gottsmann J (2008) A review on collapse caldera modelling. In: Gottsmann J, Marti J (eds) Caldera volcanism: analysis, modelling and response. Developments in volcanology 10, Elsevier, pp 233-283

Mayer K, Scheu B, Yilmaz TI, Montanaro C, Gilg HA, Rott S, Joseph EP, Dingwell DB (2017) Phreatic activity and hydrothermal alteration in the valley of desolation, Dominica, Lesser Antilles. Bull Volcanol 79:82

Melekhova E, Schlaphorst D, Blundy J, Kendall JM, Connolly C, McCarthy A, Arculus R (2019) Lateral variation in crustal structure along the Lesser Antilles arc from petrology of crustal xenoliths and seismic receiver functions. Earth Planet Sci Lett 516:12-24

Newman S, Lowenstern JB (2002) VolatileCalc: a silicate melt-H2O$\mathrm{CO} 2$ solution model written in visual basic for excel. Comput Geosci 28(5):597-604

Parat F, Holtz F, Feig S (2008) Pre-eruptive conditions of the Huerto andesite (fish canyon system, San Juan volcanic field, Colorado): influence of volatiles $(\mathrm{C}-\mathrm{O}-\mathrm{H}-\mathrm{S})$ on phase equilibria and mineral composition. J Petrol 49(5):911-935

Pichavant M, Martel C, Bourdier JL, Scaillet B (2002) Physical conditions, structure, and dynamics of a zoned magma chamber: Mount Pelée (Martinique, Lesser Antilles arc). J Geophys Res 107(B5)

Pichavant M, Costa F, Burgisser A, Scaillet B, Martel C, Poussineau (2007) Equilibration scales in silicic to intermediate magmas Implications for experimental studies. J Petrol 48:1955-1972

Pichavant M, Poussineau S, Lesne P, Solaro C, Bourdier JL (2018) Experimental parametrization of magma mixing: application to the AD 1530 eruption of La Soufrière, Guadeloupe (Lesser Antilles). J Petrol 59:257-282

Plail M, Barclay J, Humphreys MCS, Edmonds M, Herd RA, Christopher TE (2014) Characterization of mafic enclaves in the erupted products of Soufrière Hills volcano, Montserrat, 2009 to 2010. In: Wadge G, Robertson REA, Voight B (eds) The eruption of Soufrière Hills volcano, Montserrat from 2000 to 2010. GSL Memoirs 39, pp 343360

Prouteau G, Scaillet B (2003) Experimental constraints on the origin of the 1991 Pinatubo Dacite. J Petrol 44(12):2203-2241

Putirka KD (2008) Thermometers and barometers for volcanic systems. Rev Mineral Geochem 69(1):61-120 
Reubi O, Nicholls IA (2005) Structure and dynamics of a silicic magmatic system associated with caldera-forming eruptions at Batur volcanic field, Bali, Indonesia. J Petrol 456(7):1367-1391

Ridolfi F, Renzulli A (2012) Calcic amphiboles in calc-alkaline and alkaline magmas: thermobarometric and chemometric empirical equations valid up to $1,130^{\circ} \mathrm{C}$ and $2.2 \mathrm{GPa}$. Contrib Mineral Petrol 163(5):877-895

Roobol MJ, Smith AL (2004) Geological map of Dominica, West Indies. Geology Department, Univ Puerto Rico at Mayaquez

Sato H, Nakada S, Fujii T, Nakamura M, Suzuki-Kamata K (1999) Groundmass pargasite in the 1991-1995 dacite of Unzen volcano: phase stability experiments and volcanological implications. J Volcanol Geotherm Res 89:197-212

Sauerzapf U, Lattard D, Burchard M, Engelmann R (2008) The titanomagnetite-ilmenite equilibrium: new experimental data and thermo-oxybarometric application to the crystallization of basic to intermediate rocks. J Petrol 49(6):1161-1185

Scaillet B, Evans WE (1999) The 15 June 1991 eruption of Mount Pinatubo. I. Phase equilibria and pre-eruption P-T-fO2-f $\mathrm{H} 2 \mathrm{O}$ conditions of the dacite magma. J Petrol 40:381-411

Schlaphorst D, Kendall JM, Collier JS, Verdon JP, Blundy J, Baptie B, Latchmann JL, Massin F, Bouin MP (2016) Water, oceanic fracture zones and the lubrication of subducting plate boundaries-insights from seismicity. Geophys J Int 204(3):1405-1420

Self S, Rampino M (1981) The 1883 eruption of Krakatau. Nature 294: 699-704

Self S, Rampino M, Newton MS, Wolff JA (1984) Volcanological study of the great Tambora eruption of 1815. Geology 12:659-663
Sigurdsson H (1972) Partly-welded pyroclast flow deposits in Dominica, Lesser Antilles. Bull Volcanol 36:148-163

Smith AL, Roobol MJ, Mattioli GS, Fryxell JE, Daly GE, Fernandez LA (2013) The volcanic geology of the mid-arc island of Dominica. Geol Soc Am 496

Solaro C (2017) Storage conditions and dynamics of magma reservoirs feeding the major pumiceous eruptions of Dominica (Lesser Antilles Arc). $\mathrm{PhD}$ thesis, Univ Paris Diderot, France

Sparks RSJ, Sigurdsson H, Carey SN (1980) The entrance of pyroclastic flows into the sea I. oceanographic and geologic evidence from Dominica, Lesser Antilles. J Volcanol Geotherm Res 7(1-2):87-96

Wadge G (1984) Comparison of volcanic production rates and subduction rates in the Lesser Antilles and Central America. Geology 12:555558

Wadge G, Shepherd JB (1984) Segmentation of the Lesser Antilles subduction zone. Earth Planet Sci Lett 71:297-304

Waters LE, Lange RA (2015) An updated calibration of the plagioclaseliquid hygrometer-thermometer applicable to basalts through rhyolites. Am Mineral 100:2172-2184

Wilson CJN (2001) The 26.5 ka Oruanui eruption, New Zealand: an introduction and overview. J Volcanol Geotherm Res 112

Wilson CJN, Blake S, Charlier BLA, Sutton AN (2006) The 26.5 ka Oruanui eruption, Taupo volcano, New Zealand: development, characteristics and evacuation of a large rhyolitic magma body. J Petrol 47(1):35-69

Ziberna L, Green ECR, Blundy JD (2017) Multiple-reaction geobarometry for olivine-bearing igneous rocks. Am Mineral 102: 2349-2366 